\title{
Recording the Great War: military archives and the South African official history programme, 1914-1939
}

\author{
Ian van der Waag •
}

The First World War marked a revolt against the traditional mode of official history as conceived and written by the General Staffs and taught at the Staff Colleges. After 1918, the publics in various countries, having experienced massed mobilisation and the impact of total warfare, demanded an explanation for the sacrifices so many had been called on to make. This more inclusive approach rejected the nineteenth-century, Staff College predilection for campaign narratives focussing narrowly on "lessons learned". The South African tradition of official history dates from this period. This article outlines the creation of the first military archival organisation in Pretoria and analyses the South African First World War official history programme. It explores the apparent motives behind the programme and reveals the often-difficult relationships between the historians and their principals at Defence Headquarters and the tensions between the two modes of official history.

Keywords: First World War, historiography, war memory, military archives, official historians, Leo Fouché, Hugh Wyndham, Johann Leipoldt, John Buchan, John Collyer

\section{Opening the writing cabinet}

To think that 100 years hence people will still be scribbling hard and arguing over the war - I'd like to know what they'll say about us - "In 1914 the feeling of the British public was" etcetera and they'll lay down the law about what we should have felt and how different they in 2014 would have acted - I wonder what it will be like then. ${ }^{1}$

Maud Wyndham penned these lines in May 1920. Her reference here to 'the British public' must be read in an imperial sense. It embraced the public throughout the British Empire; by definition, the many millions of British subjects not born in the United Kingdom, but affected by the multifarious impacts of a global, imperial war. She was close to the writing of the history of the German South West Africa (GSWA) campaign. Her husband, a shadow defence minister, was its first historian. Mrs Wyndham came from an establishment family and grew up imbued with a sense of history and of its importance and she revelled in it, experiencing history-in-the-making on a near daily basis and having the standing and ability to place these events on record and, in so doing, record and generate a substantial correspondence with like-minded Greater Britons in South Africa and the United Kingdom and elsewhere. ${ }^{2}$ She recognised that official historians have the first word in a story that would not only enjoy currency, but involve more than a measure of public interest, perhaps even controversy, one hundred years hence. ${ }^{3}$

The Union of South Africa entered the First World War in mid-September 1914 after a difficult political process. Just four years old when the fatal shots were fired in Sarajevo, the Union's status as a

Ian van der Waag, MA (Pretoria), PhD (Cape Town), is Professor of Military History and Head of the Department of Military History, Faculty of Military Sciences, Stellenbosch University. His Military History of Modern South Africa was published by Jonathan Ball in August 2015. He is editor of Scientia Militaria: South African Journal of Military Studies and on the editorial board of the Journal of African Military History (JAMH) and founder-director of the War and Society in Africa conference series. 
British Dominion was contested by large numbers of South Africans. Moreover, the Union Defence Force (UDF), an amalgam of three divergent military systems, had been founded only two years before. Organisationally and doctrinally untested in 1914, the UDF performed meritoriously in German South West Africa, German East Africa, France and the Middle East, although active campaigning stopped briefly during the last months of 1914 to suppress a rebellion within South Africa and for the UDF to undergo rapid wartime reform. While the war experience did little to heal a young, divided nation - some 254666 South Africans served in uniform ${ }^{4}$ - the Botha government remained hopeful that the war, and the writing of the history of the war experience, might be used to build patriotism and forge some common feeling.

There was some war hysteria and flag-waving by the Unionists in 1914, but the general public greeted the outbreak of hostilities with great hesitancy. ${ }^{5}$ Regardless of political sympathies, the South African public wanted to know what was happening: What bargains had been made with London? What role South Africa would play in an unfolding war? Why the UDF was being mobilised? And where Springbok troops would serve? Rumourmongering was infectious and assumed epidemic proportions, made worse by the blanket of secrecy thrown over the very visible movement of troops and ships. ${ }^{6}$ The need to manage public opinion, tied closely as it is to the maintenance of home front morale, was obvious. Yet, while the press could help allay public anxiety and raise relief funds, pressmen were annoyed by the censorship arrangements, which had been imposed and run by bureaucrats, often aging officers, under the direction of the Department of Defence. Disappointment increased when, despite expectation, it became apparent that war correspondents would not be allowed to go to the front. This displeasure, regarding the inadequacy of information on the progress of the war and the doings of South African troops, extended to the public and was magnified in September 1914, after the South African declaration of hostilities, by the outbreak of the Afrikaner rebellion and the disaster at Sandfontein. ${ }^{7}$ The government pressed, adopted a sequence of measures to satisfy the public demand for more news, a demand that grew steadily stronger over the following months. These steps included the decision to allow a limited number of correspondents up to the front. They would, in the words of Philip Graham, publisher of The Washington Post in the 1960s, write the first rough draft of the history. ${ }^{8}$ Secondly a bureau was established inside the Department of Defence, which would provide summaries of casualties and be a place where soldier's wives could make complaint and receive news. ${ }^{9}$ And, thirdly, an official history programme was started in late 1914 and saw the appointment of a succession of official historians: Prof Leo Fouché, Lt Col the Hon Hugh Wyndham, Capt Johan Leipoldt, Col John Buchan, and Brig Gen John Collyer. Official history, defined usefully by Robin Higham, exists when 'the authors have had access to classified official documents and to a variety of authoritative persons, have had financial or other support, and that in many cases they have written from within an official office.' ${ }^{10}$ These five men - Fouché, Wyndham, Leipoldt, Buchan and Collyer - conform to Higham's interpretation.

The first overview of the development of South African official historiography was written by Jan Ploeger and published in Militaria in 1989 as part of a special issue focussing on military research in South Africa. ${ }^{11}$ This is a short chronicle, inaccurate in many respects and lacking in nuance and detail: there is for example little context and no mention of some of the official historians. When the opportunity offered I translated this and added new material for a chapter published in 2000 as part of Robin Higham's multivolume, world anthology on official military history. ${ }^{12}$ Further research, informed by a symposium on official history convened by Jeffrey Grey at the Australian War Memorial in Canberra in 1998, led to a chapter in Jeff's book The Last Word ${ }^{13}$ But these were broad sweeps spanning a century of South African official history and, with the exception of Bill Nasson's short piece on Buchan,,${ }^{14}$ there has been no drilling down, no sophisticated treatment approaching Tim Cook's work on the writing of Canada's world wars or Jenny Macleod and Mesut Uyar on Gallipoli. ${ }^{15}$ Nasson mentions Buchan and The Union of South Africa 
and the Great War as official history and then Collyer, Robinson and Whittal, as accounts written by officers and journalists, but these are not placed in their publication settings.

This article does two things: it outlines the establishment of the archival organisation in the Department of Defence and examines the first, official attempts at the writing of a history of South Africa's Great War experience, a history programme broadly aimed at nationbuilding but imbued with controversy from the start.

\section{Documenting the war: the creation of a military-historical and archival organisation}

A General Information Bureau (GIB) was established at Defence Headquarters (DHQ) on 1 October 1914 to serve as the official information link between the troops in German South West Africa and the South African public. The Bureau dealt with enquiries of all sorts - missing persons, pay problems, lists of rebels caught and Germans interned, Union Defence Force casualties - and released reports regarding the progress of the campaign. This was done to counteract the conflicting reports appearing in the local press and to buoy civilian morale. The Bureau closed following the surrender of the German forces in South West Africa on 9 July $1915 .^{16}$

By the end of 1915, South African troops were on their way to East Africa where they engaged the German troops under Lettow-Vorbeck in unison with British imperial and colonial troops. This necessitated a different type of liaison office and as a result, an office not dissimilar to the GIB, was established on 15 September 1915. This office, known as the Officer in Charge of Records, Imperial Service Contingents (or OC Records for short) opened and maintained a personal file for each volunteer serving with the Imperial forces in East Africa and later further afield. To assist the OC Records, record offices were opened at various military centres within the Union and with the South African expeditionary forces, at Potchefstroom and Roberts Heights for all units mobilising there, at Kimberley for the Cape Auxiliary Horse Transport companies, in Cape Town for the $1^{\text {st }}$ and $2^{\text {nd }}$ Cape Corps, and in Pietermaritzburg for the $10^{\text {th }}$ SA Horse. These record offices together with those in the field, were under the control of the OC Records, and every man recruited for any Imperial Service Contingent (with one exception) was required to pass through the hands of one of them. ${ }^{17}$

Record keeping did not always take place optimally and a number of troops arrived in the East African theatre with no record of them having been made in the Union. A record office opened in Nairobi in January 1916, which was transferred that November to Dar-es-Salaam, then the principal port of evacuation from the East African theatre. ${ }^{18}$ As a result, accurate nominal rolls of the men who had served in East Africa were drawn up; stringent orders had been given that no unit was to leave the theatre until a complete and accurate roll of those embarking had been compiled. ${ }^{19}$ This reveals something of the type and importance of the work carried out by this particular record office as well as the apparent record chaos that seemingly dogged the first South African contingents despatched to East Africa in 1915. This instruction, and its application in all theatres, led to the remarkable collection of personnel files for the 254666 South Africans that served in uniform during the First World War. The OC Records was also tasked with the compilation of historical information on certain South African units in accordance with paragraphs 1930 and 1931 of the King's Regulations. ${ }^{20}$ These historical narratives proved a boon to the coming official historians. The first steps had been taken to create an archival and military-historical organisation in the field.

The management of the enormous amount of paper generated by the UDF, in the form of personnel files and general correspondence files, was a daunting task for the various sections at DHQ level and right down to the lowliest unit in the field, all of which contributed to the creation of an enormous holding of correspondence and personnel files. An intensive demobilisation followed the conclusion of hostilities in 
November 1918. Some 240000 troops had to be returned to civilian life and the OC Records was tasked to facilitate this by providing service records from the personnel files. He also managed the post-war administration of the volunteers, including the issue of war stars and medals. By November 1918, with so much documentation no longer needed for administrative purposes, the Department of Defence probably became the first post-Union government department for whom an archives depot was fully justified.

Albert Basden, the Chief Clerk Defence, recognised the urgency to transfer to a place of storage all records, especially those of units and formations demobilising and disbanding after November 1918. ${ }^{21}$ He suggested that this should be the central registry at DHQ, which fell under him. Basden wrote to Sir Roland Bourne, the Secretary for Defence, that it was 'desirable to make as early a start on this as possible so that we may be ready to take over the records, for final indexing and disposal in the Archives, of those offices which will close down as circumstances permit. ${ }^{, 22}$ Bourne, as administrative head of the department, issued an instruction in January 1919 ordering the collection, classification and indexing of records accumulated during the war. The section heads at DHQ and commanding officers of units were instructed to carefully sort files in their custody into three categories: ephemeral records - for immediate destruction; records that should be retained for a few years only, and then be destroyed; and records that should be preserved as permanent archives. The ephemeral records were to be destroyed in situ, once the local officer in charge was satisfied, and the remainder were to be transferred to Pretoria, where they were to be centralised in a special section of the central registry. ${ }^{23}$ However, this move by the Secretary and his defence clerks, which led to the creation of a permanent military-archival organisation in South Africa, was contested.

The friction between the military and civilian sections of the department, and between Lt Col Harvey (the OC Records) and the civilian clerks of the Defence Secretariat, surprised no one. In effect a second record office was to be established as a branch of the Central Registry, alongside Harvey's wartime office, which now faced imminent closure. Both clamoured for recognition and for future employment as the official, post-war, archives organisation in the Department of Defence. The competition erupted the moment Bourne issued his January 1919 instruction. The lines were drawn for a showdown, but the question was decided by the Chief of the General Staff, Brig Gen JJ Collyer, in February 1919. He instructed that the work would devolve upon the Central Registry, an office common to all departments in the UDF. ${ }^{24}$

Collyer, who was nearing retirement and still wanted to turn his hand to the writing of some official history, instructed GH Byrnes, a clerk in the Defence Secretariat and soon the "Custodian, War Records", to identify documentation for transfer to the new archival section Byrnes was establishing. ${ }^{25}$ The archives section, under the direct control of the Secretary for Defence, was established with effect from 1 August 1919 and housed in the old ZAR Artillery Barracks behind Defence Headquarters in Dequar Road. Soon records were being received from all sections, branches, bases, camps, hospitals and depots, both within the Union and from East Africa and Europe. By October 1919 Byrnes had three clerks under him and they sorted, card indexed, and stored incoming archival material and made files easily retraceable. However, troubles were many. ${ }^{26}$ Sometimes commanding officers took their unit correspondence files home on retirement and some were unwilling to part with them. ${ }^{27}$ In other instances, the volume of material was so great that sheer size prevented transfer to the Artillery Barracks. However, despite the teething problems and the perhaps inevitable clashes between the military officers at DHQ and the civilians in the Defence Secretariat, an archives organisation had been created at Defence Headquarters. ${ }^{28}$

The centralisation of records was problematic. In 1918, military personnel records were administered by no less than four separate offices (table 1). The centralisation of personnel files, initially in the office of the OC Records, started in earnest 1919, but, that October, priority was given to the 'out station records' generated at military district level. As should be expected, these records varied greatly in 
terms of their nature and the office of origin. For example, the first consignment received from No 1 Military District, headquartered in Cape Town, included the archives of the Officer Commanding, Base, the General Depot at Rosebank, the General Depot at Wynberg, the Military Embarkation Staff Officer, the SA Engineer Corps, and the Commando Depot at Green Point, the Artillery Training Depot, the Cape Auxiliary Horse Transport Company and the Cape Cyclists. ${ }^{29}$ By the end of November 1919, nineteen consignments had been received from some thirty distinct offices. In the case of the Cape Mounted Riflemen and the SA Mounted Riflemen, the volume of archivalia was so great that they filled 100 crates and it took 20 pounds of nails to seal the lids. A disposal board was convened on the spot and a destruction of material classed as ephemeral followed. ${ }^{30}$

\begin{tabular}{|lll}
\hline Serial & Category of personnel record & Custodial office \\
\hline 1 & South West Africa campaign & Adjutant General \\
2 & East and Central Africa campaigns & OC Records \\
3 & Overseas Contingents & OC Records \\
4 & UDF personnel & Adjutant General \\
5 & Imperial Service Contingents in the Union & OC Records \\
6 & Native Labour Contingents & Department of Native Affairs \\
7 & Unit personnel files & Custodian of War Records, Defence Secretariat
\end{tabular}

Table 1: Administration of military personnel records, 1918.

The centralisation of archives caused other problems. In some cases, contrary to accepted practice, the archives of different units were amalgamated or divided into one or more larger archival groups. In August 1920, the records of the South African Expeditionary Force arrived from London. Distinct archives groups were not described and arranged separately, but catalogued together with the archives of the $12^{\text {th }}$ Infantry Brigade, received from the Chief Ordnance Officer, to form a collection known as "World War 1, Imperial Service Contingents." This destroyed the original order of the documents and deprives the historian of important information regarding the way in which the archives came to be produced and deposited. The same things happened again in 1921, when the records of the units that served in the South West African Protectorate after the campaign had ended, were transferred from the Adjutant General's Section to the War Records branch. These records included the correspondence files and card indexes of the $1^{\text {st }}$ and $2^{\text {nd }}$ Regiments of the Military Constabulary, the Police Training Depot, the Protectorate Garrison Regiment, administrative services, and medical services. ${ }^{31}$ Logically, the medical records might have been taken up in the archive of the Director Medical Service, while the other groups of files should have been sorted and catalogued as separate entities. However, these files were amalgamated and divided into two large collections: most of the correspondence was amalgamated to form a collection called "Adjutant General 1914/1921", while the orders and instructions issued by the respective units, together with those received from higher headquarters, were emerged in a collection called "Orders 1914/1918". The same happened with the files from the expeditionary contingents and explains the presence of the large number of "World War 1" collections in the custody of the Military Archives in Pretoria, each of which contains the files of different offices of origin and based on themes, such as "German South West Africa", "WWI Diverse", and "WWI Diaries and Appendices". This thematic grouping of material in collections may have been done to assist the historians in the writing of the campaign histories. Alternatively, as we shall see, the collections may be a consequence of their trawling and gathering. 
However, the opposite also occurred. In several instances archives groups were split up and dispersed between a number of archives depots and offices. In 1920, for example, the records of the Prisoners of War Internment Camp at Pietermaritzburg were divided between the Departments of Defence and the Interior. The War Records branch received the personnel files of the camp guards, who were members of the UDF. War Records already held the Provost Marshal archive (references PMK and PMP) and a portion of the files of the Commissioner of Enemy Subjects. The placing of all of the Internment Camp files at War Records would have brought the archives of these related offices together. ${ }^{32}$

The personnel records of the coloured and black units that served during the First World War is another case in point, although the archives generated by these same units had already seen transfer to War Records. In 1929, the Director of Native Labour wished to transfer the personnel files, generated by the Department of Natives Affairs during the war, to the central archives of the Department of Defence. They were the personnel files for black and coloured labourers and servicemen in the South African Native Labour Contingent, the Cape Coloured Labour Regiment, the Cape Auxiliary Horse Transport Corps, the Native Labour Corps (South West Africa), the Native Labour Corps (East Africa), and the SA Field Artillery. However, the military authorities were interested only in the records of the personnel who had actually attested for service in the UDF. As a result the archives were split up in 1930. The defence archives took custody of records relating to the European personnel attached to these units, while the Chief Archivist (Union Buildings) received the records relating to the coloured and black personnel, all of whom had been unattested..$^{33}$

The management and centralisation of military records was closely connected to the start of the official history programme in South Africa and production of the first, official, campaign narratives. Centralisation was difficult and had been undermined, in some instances, by zealous, demobilised officers. In several cases - the SA Veterinary Corps ${ }^{34}$ and the Water Supply Corps ${ }^{35}$ for example - archives were in the possession of previous commanding officers, who had taken their unit correspondence files home after the war and were unwilling to part with them when called on to do so after 1919. These difficulties and the corrective measures, related closely to the management of records used by the first official historians, affect historical research conducted in the Military Archives (SANDF Documentation Centre) today.

\section{Writing the war}

The writing of an account of the South African campaign in German South West, and of the rebellion in South Africa and its connection with the greater war in Europe and elsewhere, was first mooted in December 1914 by Thomas Fisher Unwin, a London-based publisher, just as the second invasion of German South West Africa was getting underway. ${ }^{36}$ This was followed by several requests for information on the campaign or for appointment as an official campaign historian. ${ }^{37}$ Requests for information were met, although mostly only in part, by the GIB.

The various accounts of the German South West campaign, written by war correspondents and individual soldiers supportive of the government's war policy, form the start of South Africa's First World War historiography. ${ }^{38}$ Among the first to appear were WS Rayner and WW O'Shaughnessy, How Botha and Smuts Conquered German South West: a full record of the campaign, and JP Kay Robinson, With Botha's Army. ${ }^{39}$ The first was published by Leo Weinthal, the chief editor of The African World, and issued in aid of the New Dominions Wing of the Union Jack Club, the Governor General's Fund, and The African World Red Cross. Weinthal was an interesting man. He had been editor of the Pretoria Press and chief correspondent of the Reuters news agency in the Transvaal before 1899, when he had worked with Roderick Jones, owner-director of Reuters in 1915 and an associate of the British propaganda structure based at Wellington House. ${ }^{40}$ How Botha and Smuts Conquered 
German South West, and the personal, soldier's accounts that followed from 1916, naturally reflect the one-sidedness of the wartime propaganda generated at the time between the government and a willing press. ${ }^{41}$ These books were all generally praised, ${ }^{42}$ although it should be noted that, as a corpus of war literature, they are still in need of a serious historian. ${ }^{43}$ They were essentially personal accounts, lacking references and academic scaffolding. And none received sanction as an official campaign history.

In August 1915, after the conclusion of the German South West campaign, JP Kay Robinson approached the Department of Defence. He had served throughout the campaign with the Imperial Light Horse and now sought appointment as a campaign historian. With the campaign at an end and facing the prospect of a widening war - new contingents were being raised for service in East Africa and Western Europe - the defence authorities were pressed to formulate policy regarding an official, war history programme. A number of principles were now laid down. The first related to access, and particularly firsthand access to the archives generated during the war, and the associated security concerns. Any militaryhistorical research, Colonel John Collyer, then Chief Staff Officer, informed the Secretary for Defence, would have to be done 'under the strictest supervision. ${ }^{44}$ Some would claim that the professed 'official' nature of military records and their supposed inaccessibility was nothing other than an excuse to keep military documents 'closed'. The second principle related to ability. A number of officials very much doubted - in view of the technical nature of military history - whether just any member of the public would ever be in a position to write such a narrative. Collyer even called for the exclusion of civilians from the writing of military history per se. Civilians, he argued, simply did not have the skills, the unique combination of education (although not necessarily university-based in his own case), the ability to search out a military matter and to write up the findings, and, most importantly, a thorough knowledge of the Defence organisation, its structure, ethic and the milieu in which it operates both in times of peace and war. ${ }^{45}$ At the very least, a civilian historian would have to be assisted and advised and, in 1915 when Robinson made inquiry, the staffs at Defence Headquarters were thought sufficiently busy without being taxed by pesky 'civilian' researchers and would not be able to render assistance until the war was over. ${ }^{46}$ Robinson's credentials - he had served throughout the campaign with a Citizen Force regiment, the ILH were seemingly deemed inadequate. ${ }^{47}$

However, there was a growing realisation too that the history writing could not be left entirely to soldiers. For one, there was a growing public demand for a history of the Union's war effort and the matter could not wait until the conclusion of hostilities, when capable officers would become available. Moreover, any official history would have to be a good read and, at the same time, meet the nationbuilding goals of the Botha government. A soldier's account might not meet these objectives. Gertrude Page (1872-1922), a popular Rhodesian writer of light dramatic novels, was proposed in 1916 as a possible solution. We do not know who suggested her, but she was initially identified as the possible writer of a history of the South African forces in France. ${ }^{48}$ Her credentials seemed impeccable. Page was a household name and a bestseller, her Paddy The Next Best Thing (1908) sold more than 300000 copies. Some thought her to be the Kipling of Rhodesia. Her heroes were of the bronzed English public school type, having titles and double-barrel surnames and seemingly ready for an adventure at the drop of a hat. It did not seem to matter whether these exploits happened in Central Africa, somewhere along the Zambezi, or astride the River Somme. But Collyer's ideas had by then gained traction at Defence Headquarters and a number of decisions were reached: an official historian, when appointed, would be a serving officer of the Union Defence Force. It may come as little surprise that four of the five historians closest to the South Africa's Great War official history programme were senior officers with first-hand military experience gained both in the field and at Defence Headquarters. 


\subsection{Leo Fouché and the Rebellion Commission}

The exception was Professor Leo Fouché (1880-1949), the first of these official historians, who was appointed in late 1914, before the decisions regarding the writing of official history were made. Fouché had studied at the Victoria College, the forerunner of Stellenbosch University, before going on to Europe for postgraduate studies at the universities of Leiden, Paris and Berlin. His doctorate ('Tien jaren uit de wordingsgeschiedenis der Boeren, 1652-1662') was awarded by the Rijksuniversiteit Ghent. Fouché was appointed in 1909 to the history chair at the newly-founded Transvaal University College (TUC), later the University of Pretoria, where he opposed the Afrikanerization of the university and of the history programme there. Controversy seemed to dog him. ${ }^{49}$

Fouché served briefly as Smuts's private secretary after the outbreak of war in 1914, when he was approached by Smuts to investigate and write an historical report on the causes of the Afrikaner Rebellion. This was of Gordian complexity. A parliamentary select committee had been appointed to enquire into the rebellion and, as one of its members predicted, this was 'a long [and] very unsatisfactory affair.' It was 'too soon to begin enquiring into the causes', and 'most of those immediately concerned [were] either on service in German S.W. or in prison awaiting trial - some on capital charges. ${ }^{50}$ Moreover, although comparatively brief, the 1915 parliamentary session was consumed by lengthy, volatile oration, which intensified the 'great bitterness' of the Nationalists and produced the final break between Botha and Smuts and the Afrikaner right. Fouché's report, 84 pages in length and published as a government blue book, was tabled in parliament amidst this atmosphere. ${ }^{51}$ His criticism of the rebels was scorned by the majority of Afrikaners who, already objecting to his brand of history at the TUC, dismissed his Rebellion report as nothing but a poor and ill-disguised attempt at government propaganda. He was criticised for failing to place the rebellion into its fuller, historical context and for serving as a government apologist. His friends, Fouché later noted, 'refused to greet him and treated him as though he were a leper or criminal. ${ }^{52}$ An obituary in The Star in 18 March 1949, however, reported that 'his objectivity offended those who sympathised with the rebels and marked the beginning of his estrangement from the pronounced nationalistic spirit' of the Afrikaner. ${ }^{53}$

In the meantime, through 1915, the Imperial government urged the Botha government to produce a dispatch on the Rebellion. Promises were made to London and, again at the request of Smuts, Fouché started in October 1915 on 'a careful history of the rebellion and in special connection with its connection with Germany and the Protectorate. ${ }^{54}$ Major Johann Leipoldt, an officer on the General Staff, was ordered to collect and collate evidence in Windhoek and have this sent to Fouché's office at the Transvaal University College. ${ }^{55}$ Smuts 'wished no pains spared. ${ }^{56}$ Material soon started to arrive. There were the Kriegnarichten Nos 1 to 15, from the German military archives, and original German telegrams, found by the intelligence officer at Chamis Station, some of which referred to Maritz and the Rebellion. There were newspapers published in the territory during the hostilities, including, the Nieuwe Weekblad (published for the Dutch speaking South Africans in the territory) from 2 September 1914 through to 3 March 1915, the Sudwest, from 7 August 1914 to 29 December 1914, and the Sudwestbote, from 7 August 1914 to 10 May 1915, as well the Ambtsblatt of 16 September 1914, containing a proclamation by Governor Seitz constituting the South African Volunteer Corps. Other material included the original posters issued by Maritz containing his proclamation to the people of South Africa, and copies of letters, in roneo, signed by Andries de Wet and Pieter de Wet, calling upon Afrikaners to support the German cause. ${ }^{57}$ Fouché's dispatch, sent to the Dominions Office, probably informed the manuscript history on "Operations in the Union of South Africa and German South West Africa" produced after the war by the historical section in the Cabinet Office in London. ${ }^{58}$

Fouché was not a military man. His first brief focused on the causes of the Rebellion, his second on the German connection. Avoiding the military operations he produced political history, touching on 
some of the social issues. ${ }^{59}$ That it was not military history as such, may have been a consolation to Collyer, who wanted to save the work of official historian for himself. However, public pressure and the pressing need for an official history programme and the fostering of nationbuilding, led to the appointment from late 1916 of a sequence of official campaign historians. In terms of background, they differed markedly from Fouché.

By 1916, nothing had yet been done with regard to the writing of the history of the German South West African campaign, which had been concluded in May of the previous year. The absence of a manuscript was becoming something of an embarrassment. ${ }^{60}$ The immediate problem lay in the identification of an historian, who - to the mind of the Defence authorities - had the requisite skills. Catalogued by Collyer, these skills included a theoretical and technical knowledge of the military as an organisation, as well as the security requirements of strict supervision, limited access to official sources and the inability of the defence staff, already overtaxed by the war, to lend a hand. ${ }^{61}$ The most eminent candidate appears to have been Collyer himself, who had served on General Botha's staff during the campaign and had earlier expressed a wish to write the history of the campaign. ${ }^{62} \mathrm{He}$ was, however, unable to make headway with it between the end of the operations in South West Africa and his departure for German East Africa at the beginning of 1916 as Smuts's chief of staff. The Secretary for Defence, Roland Bourne, realising that Collyer would have his hands full even when the East African campaign was at an end, approached Smuts in November 1916 to appoint two old friends and colleagues from 'Kindergarten' days to undertake the work.

\subsection{Hugh Wyndham, the German South West campaign and the war of reputations}

Taking Bourne's advice, Smuts approached two lieutenant colonels - Hugh Wyndham and John Buchan - to write the official histories of the German South West campaign and of the South African contribution to the war on the Western Front. Wyndham and Buchan seemed sensible appointments. Both were Oxford graduates with a grounding in History, they had a knowledge of South Africa, and both had a military background. They seemed to tick all of Collyer's boxes. They were also good friends; they had shared a house in Johannesburg, when they had served on Milner's staff, and in 1907 Wyndham was Buchan's best man.

Hugh Archibald Wyndham (1877-1963) was the embodiment of a nineteenth-century English country gentleman. A younger son of a well-connected family, he immigrated to South Africa in 1901 and served briefly on Milner's staff before settling in the Standerton District, where he led the life of a landed gentleman. He was appointed to the command of the Southern Mounted Rifles in 1905, a position he held until 1912, and was for ten years a Unionist member of parliament, advocating stronger ties with Britain. He did not integrate into the UDF and was stripped of his command by General CF Beyers, who did not like his politics. ${ }^{63}$ Amidst the dramatic bouleversement of mid-September 1914, however, Wyndham was appointed as Chief Intelligence Officer for the Union, which gave him insight into the operational planning and execution of the German South West campaign. He served on the South West Africa Diamond Commission in May 1915, but, unable to secure an ADC-ship in France, he was back in South Africa in September $1915 .{ }^{64}$ Disillusioned and disappointed, by the rise of Afrikaner nationalism and international syndicalism, he returned permanently to England in 1923 and, in 1952, succeeded his brother to the family titles and estates. He was a local and family historian of some note and contributed a chapter to the South Africa volume of the Cambridge History of British Empire. He was the embodiment of everything about the Empire that the Afrikaner nationalists had come to hate. ${ }^{65}$

Notwithstanding, in November 1916, Wyndham was appointed to write what became the first official history of the campaign in German South West Africa. Smuts had been under pressure for some 
months to produce such a history, again in the form of a dispatch for London, and Wyndham seemed not a poor choice. A volunteer soldier with a university education, he knew something of the historical method and had the military-technical skills deemed necessary for the work. Furthermore, being under military discipline, he would not require supervision and would have, in theory at least, unlimited access to official sources. Moreover, his term as chief intelligence officer had given him a close and very intimate knowledge of the campaign, while his seat in parliament had given him a vantage point from which to observe the intrigue that had cloaked government circles before the commitment of South African forces and the outbreak of the rebellion in 1914. And then, from a personal point of view, Wyndham was a man of leisure, seeking some military role during the parliamentary recess. Before Smuts had even been approached, Wyndham had already responded to Bourne's overtures and indicated a willingness 'to work up [the] available material' and 'supplement it where necessary' from his own personal experiences. ${ }^{66}$ Bourne indicated too that Wyndham's manuscript would be revised later by Collyer, who would also add portions that dealt specifically with General Louis Botha's operations along the Swakop River valley. ${ }^{67}$

The work started in November 1916. Wyndham was attached to the Adjutant General's Section at Defence Headquarters and spent that November and December wading through records. He expected the project to 'take at least a year' ${ }^{68}$ : in between he would return to Cape Town for the parliamentary session and perhaps have a field trip to South West Africa ${ }^{69}$ He professed to 'always loathe' Pretoria ('at the best but a stuffy hole'70) but the work delighted him. He stayed with Bourne and dined occasionally with the Buxtons at Government House - enjoying the constant flow of high-grade political and military news - and returned to Johannesburg for the weekends. Maud, equally eager for news, questioned him closely each weekend, and reported to her correspondents in the United Kingdom.

Hugh [she told his mother] is very busy with his despatch on the German W. campaign \& in Pretoria sits in his office all day looking up records - quite interesting - but otherwise his life there sounds dull, at least after close questioning, \& subtracting some flowers of wit such as that he's dined with Poincaré at the Elysée, I gather that he sees few people. ${ }^{71}$

Having no staff, Wyndham worked alone, ${ }^{72}$ tracing the material, working through telegrams, intelligence and situation reports and general correspondence. Unit and battalion commanders were instructed to forward material, including historical summaries, to him at Defence Headquarters. ${ }^{73}$ But, as he soon found, the 'working up of the material' proved difficult.

Wyndham experienced problems typical of any contemporary historian. The most significant of these was the state of the available material. This was, he told Maud, chaotic - 'few if any written orders or documents of any sort were kept. ${ }^{74}$ While this might have been partially true, he soon discovered that much official material existed but was unavailable. Although Bourne had ordered the centralisation of all documents relating to the South West campaign during the course of 1916, the records of the earlier stages of the campaign and of all the invading forces were in an unsatisfactory state, lying in various centres from Windhoek through to Cape Town. Records were inaccessible for other reasons too. Some regiments and units hampered access to their records and, on at least one occasion, Bourne had to intervene on Wyndham's behalf. ${ }^{75}$ And then, to complicate matters further, Bourne's operating files, which he had handed to Collyer during the previous year - when Collyer had intended to write the history - could not be immediately traced. These files contained all of the telegrams between the forces in the field and Smuts in Pretoria. ${ }^{76}$ Collyer also had in his possession all of the records of the operations under the personal and immediate command of General Botha. This problem, of official documentation in private possession, dogs countless historians. And the point might be made that even official historians do not enjoy full and unlimited access. 
Notwithstanding the time and source constraints, by June 1917 Wyndham had produced a campaign history. Unfortunately, we know little about his manuscript for it was never published and is now unavailable in its original form: searches through the National Archives in Pretoria, the National Archives of the United Kingdom, and the Hugh Wyndham Papers in the Petworth House Archives, all proved fruitless. However, there are clues that come through in the Wyndham correspondence, from the letters written by Hugh and Maud to their relatives in the United Kingdom, which reveal much. Wyndham had clearly been very critical and, as he told his mother, he had 'never expected [Smuts to] publish the whole of [his] account of the German South West Campaign. ${ }^{77}$ Always aware that any political crisis was sure to return a stronger National Party ${ }^{78}$, he felt 'much of it ought very properly to be suppressed. ${ }^{79}$ Smuts, who seemed to appreciate Wyndham's work, told his mother that he had been 'accomplishing great work of late in South Africa' and that his campaign history was excellent and very interesting. ${ }^{80}$ Although perhaps too frank and, in view of the delicate political situation, unsuitable for public consumption, Maud hoped it would eventually be published; after all, she remarked, the muddles and misfortunes in South West Africa were 'far less miserable than [those in] Gallipoli, Mesopotamia and German East [Africa].' Yet, she recognized the political considerations and, breaking a lance for British generals on other fronts, noted: 'we have got to continue thinking Botha \& Smuts \& the Boers are far finer folk than the poor British - people \& generals who can be abused \& degraded without fear of consequences'! ${ }^{81}$

Wyndham produced his manuscript at a critical juncture in South Africa's war. The battle at Delville Wood was recently passed, yet was soon dwarfed by the news from East Africa. The difficulties in transport and commissariat and the reports of 'starving troops' in German East joined the list of antiwar grievances: the overseas pay, the conduct of the campaign in Tanganyika, poverty on the East Rand, the national food question, and the employment of black servicemen in Europe ${ }^{82}$ Former-president MT Steyn also died that November, producing demonstrations of friendship between the two Afrikaner parties at the funeral. Wyndham and his fellow Unionists, while anxious, remained bound to Botha on the war issue. ${ }^{83}$ They sought to avoid a political crisis and stressed the need for nationbuilding, something that could not be achieved if the leadership and reputation, of Botha and Smuts primarily, and the pantheon of general staff officers to a lesser extent, were disparaged. If the official history was a response, albeit a feeble one at the time, to counteract negative press reports and growing condemnation of the government, Wyndham produced something else.

Wyndham's history of the campaign, if we are to believe the family correspondents, was too frank. Fortunately, a copy of the revised manuscript, the amendments being made later by Leipoldt and Collyer, has survived in the archives of the Secretary for Defence, at the Military Archives, Pretoria. However, substantially sanitised and modified it is impossible to appraise as the original Wyndham manuscript. Nonetheless a number of deductions can be made. Wyndham sought to get to grips with the new nature of warfare and the challenges facing the soldier or historian attempting to make sense of the complexity of a single campaign, let alone the whole of the war. His brother Reginald was killed in November 1914 on the Western Front. Reading Reginald's diary in February 1915, Wyndham appreciated that, while 'most interesting', it showed 'how very little a man can judge of what is going on in a modern battle. ${ }^{84}$ Any observer saw only the smallest picture and the generals, those having a strategic view, were often removed and far from the front. In German South West, however, the picture was different. The campaign was not only shorter in duration and smaller in troop numbers, but most officers, even the general officers, served right up at the front and had an intimate tactical knowledge. Some of these men produced diaries and memoirs and historical narratives of the exploits of individual units, to which Wyndham had some access. ${ }^{85}$ But the largest gap in his research was surely the inaccessibility of the German military records, which, although arranged and catalogued from October 
1915 by Major von Lagiewsky of the former German Staff in Windhoek, were still inaccessible when Wyndham completed his manuscript in 1917.

Wyndham's task was as difficult as it was daunting. He worked alone and was geographically removed from other military historians working on other fronts in this global war. He clearly enjoyed little exchange of ideas and surprisingly, although close friends, there is no exchange of letters between Wyndham and Buchan in either of their personal collections of papers during this period. Conversely, Buchan, whom Smuts approached to write the history of the South African Infantry Brigade in France, was connected to the heart of the British imperial propaganda network.

\subsection{John Buchan and the South African Forces in France}

John Buchan (1875-1940) was raised in a parsonage in the Scottish Borders, educated at Glasgow University and then Brasenose College, Oxford. 'Utterly disappointed' at the end of 1899 not to get an All Souls fellowship ${ }^{86}$ he was cut adrift from Oxford - an 'entangling place ... not favourable to the higher forms of mental or moral energy ${ }^{87}$ according to AJ Butler - and went out to South Africa, where he served for two years on Milner's staff. There he was introduced to the world of intelligence. He met and cemented enduring friendships, with Hugh Wyndham and other ardent imperialists, but also earned the respect of Generals Louis Botha and Jan Smuts for his work in resettling Boers after the Peace of Vereeniging ${ }^{88}$ This posting, which Buchan embraced as a great adventure and 'an interposition of Providence" ${ }^{89}$, set him on the path to a literary and political career. He would later represent the Scottish Universities at Westminster and receive posting to Canada as governor general in 1935.

Buchan, multitalented and industrious, worked for the publishing house Thomas Nelson and Sons when the war erupted. He enjoyed a massive literary output, which included adventure stories, several biographies, articles and reviews for magazines and newspapers. His novel The Thirty-Nine Steps, first of his Hannay series, was serialised in 1914 and published as a book in 1915. Immediately successful, it contained all of the ingredients of a good thriller: a long chase from London to Buchan's beloved Scotland, an innocent hero (Hannay) pursued both by the British police, who suspect him of murder, and German agents determined to expunge knowledge he is presumed to hold. Recruited by Charles Masterman, Buchan joined the staff at Wellington House as a writer of propaganda to help fight "the war of words". 'It was', as Taylor Downing notes, "the perfect cover. Buchan was a well-respected author writing for an independent publisher. No one would suspect that he was producing British-sponsored propaganda. ${ }^{90}$

Buchan, broke cover, so to speak, in 1916, when Haig invited him to write official communiques from his headquarters in France. He was, he confided to John Edgar, "like a stormy petrel [following] the chief war zone. ${ }^{91}$ His travels took him to the Channel Fleet and up to Scapa Flow in 1916, and through 1917 he experienced the Somme battlefields. He maintained close links with Smuts and with former members of Milner's Kindergarten: with Hugh and Maud Wyndham and with Geoffrey Dawson, the editor of The Times, whom he also knew from South Africa. ${ }^{92}$ Advancement followed quickly. In 1917 Lloyd George placed him in charge of a new Department of Information and, as Director of Propaganda, Buchan worked 'day and night in the interests of Great and Greater Britain.' 93

He also conceived and wrote the twenty-four volumes of Nelson's History of the War, which he produced through Nelson's from February 1915 through to July 1919. At the time, his diverse writings opened him to some criticism. Lloyd George, for example, held in his memoirs that:

Mr Buchan, in his History of the War, lapsing into his fictional mood, gives a fanciful picture of my meeting General Nivelle at the Gare du Nord ... When a brilliant novelist assumes the unaccustomed rôle of historian it is inevitable that he should now and again forget that he is no longer writing fiction, but that he is engaged on a literary enterprise where narration is limited in its scope by the rigid bounds 
of fact ... The real explanation is that Mr Buchan found it so much less trouble to repeat War Office gossip than to read War Office documents. ${ }^{94}$

These comments were in Liddell Hart's view 'needlessly sharp' ${ }^{95}$, but Buchan has since been criticised by historians of propaganda for a seemingly 'active jingoistic misinterpretation of the actualities of the war.' 96 Recognising the difficulties presented by his lack of distance, Buchan told Liddell-Hart in January 1917 that: 'There are very many things in the early volumes of my History which will have to be revised after the war. Historians' views like soldiers' alter during the course of the campaign. ${ }^{97}$ During the war, of course, his History of the War was immensely popular and was devoured by a victory-hungry British public. Praise poured in from all quarters. In November 1917, Britten Austin described the volumes, there were eighteen at that point, 'as among the grandest intellectual achievements this war has produced.' They were 'wonderfully precise and accurate when the limitations imposed on you are considered, your analyses of the statecraft and the war-psychology of the belligerent peoples are a revelation in this world-wide welter of confused talk. If there is another man who can comprehend these vast surgings of a world in turmoil with such a cool, all-embracing vision and acuity of judgement, he has not - so far as I am aware - shown himself. You stand alone. ${ }^{98}$ Smuts, to some extent at least, agreed. ${ }^{99}$

In 1916, Smuts approached Buchan, then in France, to write a history of the South African contribution to the war on the Western Front. Buchan was ideally placed for the work. Working at the General Headquarters of the British Expeditionary Force he had at his disposal 'all official papers'. ${ }^{100}$ Moreover, his South African links were re-cemented in the officers' messes of the South African Brigade, and gave him access to men for interviews and to the field registries for further information. Nasson tells us that 'he nosed out all available official papers and engaged in concerted lobbying of higher-level officials and senior Union Defence Forces officers for a glimpse of field orders, official journals, battle accounts, registers and similar information on the operations of the South African Infantry brigade. ${ }^{101}$ Interviewees included Major General Sir H.T. Lukin and the Brigade's battalion commanders. His ferreting for information gives the particular scope and depth to his History of the South African Forces in France, which has largely eluded subsequent historians of the Brigade.

While eminently qualified to write the official history of the Brigade in France - and it was acknowledged that the South Africans were very fortunate to get him - Buchan, like his History, was a product of his times. Like Wyndham, he was an imperialist and a Kindergartener and this permeates his work. But Buchan also believed that South Africa found herself at a crossroads. The war had provided an "historical moment", an opportunity, perhaps unique, for the forging a South African nation, one embracing both English-speakers and Afrikaners. His History stressed the uniqueness of the Brigade, as a fighting formation and as being fully representative of white South Africa. The Brigade's battlefield successes, at Halazin and Agagia, Delville Wood and the later Somme, brought glory he argued, not to the individual, but to South Africans: 'Two strong stocks, coming together ... ${ }^{102}$ The Infantry Brigade was of course small in comparison to the large numbers of allied troops in France. Buchan, lionising the South Africans, pronounced -

The little contingent, one among some hundred British brigades, occupied small space on the battlemap. But scale must not be confused with kind; the men of Leonidas were not less the Spartans because they were only three hundred. ${ }^{103}$

Alongside his nation-building metanarrative, Buchan, like his counterparts in the other settlement dominions, contributed a good deal to the construction of notions of colonial valour: that colonial soldiers were hardy, gritty, and muscular and ready to stand the breach against bellicose, despotic, imperial powers. ${ }^{104}$ If Delville Wood had become South Africa's Thermopylae ${ }^{105}$, then perhaps as Nasson quips Cape Town's Table Mountain would double as Smuts's Mount Olympus. ${ }^{106}$ 
Buchan's History of the South African Forces in France, which runs to almost 400 pages of detailed, fluent prose, was published early in 1920. Very well received, numerous notices in the Englishlanguage press applauded him and his work. He sent advance copies to friends and associates and the response was overwhelming. According to George Trevelyan, 'it could hardly have been better done. The tactical history is perfectly clear, and is interwoven with personal incidents and the sense of the collective heroism of it all, and is placed in its setting in the bigger strategy and issues which are finely touched in.' 107 Lord Buxton, the governor general of the Union, recognised both its literary and political value -

There are a good many things in your book which I shall take an opportunity of quoting in speeches. It is a real gratification to South Africans themselves, and to anyone interested in South Africa, to know that those who went Overseas should in every way have come out so well. Apart from their courage and resource when in action, and their good morale between-whiles, I have seen and received many private accounts from people in England describing them as "good fellows", who behaved like gentlemen and made themselves popular. ${ }^{108}$

The praise came from all quarters, from Smuts and Mentz, from Roland Bourne, Tim Lukin ('The record of my old Brigade is accurate and, may I be permitted to say so, most graphically written' ${ }^{109}$ ), and from Andries Brink ('... your gifted pen to place at record the heroic deeds of our South African lads in Flanders' ${ }^{110}$ ), Thackeray ('without which we should have had but little to show our youngsters and the coming generations of South Africans ${ }^{111}$ ), and from Tanner who used it for reference at the South African Military School, where he was commandant after the war, indicating too that Military History as a subject had staked its place in South African officer education. ${ }^{12}$ Tanner expressed the hope that the book would be a financial success and reward the labour it involved. Bourne had originated the idea to approach Buchan and in 1920 he gave himself a pat on the back for 'putting the kybosh on the horrid suggestion to make Gertrude Page the horn blower.' ${ }^{113}$ But Bourne very much regretted that the Union government did not 'come forward and undertake the entire financial responsibility for the publication.' This was something that Bourne, as Secretary for Defence, had fully contemplated would be done and in his humble opinion should have been done, but he understood that Botha and Smuts had decided otherwise. 'This made it necessary to curtail the size and scope of the volume a good deal which is probably a pity though I must confess I was pleasantly surprised to find how full and complete and well got up the volume is. ${ }^{114}$ Although not paid for his work, Buchan was an official historian in the sense that he enjoyed privileged access to source material and to the men of the Brigade and no doubt enjoyed material support along the way.

The History has its shortcomings. The coverage is more restrictive than the title suggests. As Buchan notes in the first chapter, he sought to follow the $1{ }^{\text {st }}$ South African Infantry Brigade - South Africa's main fighting formation in France - from recruitment in the Union in 1915, to further training in the United Kingdom, and to deployment in Egypt and France. This he does in the main body of the book, embracing the first 263 pages. The remainder of the book, a set of seven appendices, cover the Heavy Artillery Brigade and the unbrigaded South African units on the Western Front - the Signal Company, the medical services, and the engineer and transport companies. He also did not address the more than 6500 South Africans that served in France with imperial regiments and battalions and with the RFC. Yet, the SA Native Labour Contingent, raised by the Department of Native Affairs and not Defence, and the tragic sinking of the SS Mendi is perhaps the most unfortunate omission. ${ }^{115}$ In so doing, on the longer term, he scuttled his main aim of depicting the larger meaning of South Africa's role in the wider war.

Buchan's history of the brigade is a fine narrative, a literary work that stands apart from the other South African official histories. Yet, like the others, he did not indicate his sources and in this respect, the lack of referencing, Lloyd George was possibly correct: like the writer of fiction, an official historian in 1920 was content to write his narrative, while university-based historians had to substantiate arguments and document references. Buchan otherwise conformed to the traditions and principles of diplomatic and military history and was scarcely a methodological revolutionary. However, he remains the most readable 
of the official historians of South Africa's First World War experience. The next official historians, Johann Leipoldt and the retiring Chief of the General Staff, Brig Gen Jack Collyer, represented both a regression and a step forward.

\subsection{Johann Leipoldt, German South West Africa and the German military records}

Like Buchan, Johann Gottlieb Wilhelm Leipoldt (1877-1945) was a son of the manse. Both grandfathers had arrived at the Cape in the service of the Rhenish Mission Society and family connections, dating from the short-lived New Republic, brought close ties to Louis Botha and considerable political dividends. ${ }^{116}$ Leipoldt spent his childhood in the parsonage at Clanwilliam and, during the Anglo-Boer War, served as a lieutenant with the ZAR State Artillery. After the war he qualified as a surveyor at the University of the Cape of Good Hope and enjoyed a brief but successful surveying career before integration into the UDF in 1912. ${ }^{117} \mathrm{He}$ attended the first staff course in Bloemfontein and remained on at the Military School as an instructor in Military History and Tactics, reflecting the interesting utilitarian nexus between these subjects. He was a complex figure. Piet van der Byl notes that Leipoldt 'had a brilliant brain', but he was also practical and a 'casual fellow' - while on the staff course he had loaned a pair of pliers from the toolbox of Van der Byl's motorcycle and 'proceeded to pull out one of his teeth.' On another occasion, having sustained 'a fairly big and painful gash on his wrist, he sewed his skin together with three stitches, using ordinary needle and thread. ${ }^{118}$ A consequence of his surveying background perhaps, Leipoldt had an eye for detail and rejected the poor efforts of his officer-students at the Military School, where he gained a reputation as an instructor prepared to maintain standards, despite the political pressures. ${ }^{119}$

Following the declaration of war in 1914, Leipoldt briefly joined the censorship staff in Cape Town before posting to Prieska, where he served as an intelligence officer following the outbreak of the Rebellion. He succeeded Wyndham as Chief Intelligence Officer of the Union in May 1915 and concurrently saw active service in the German South West and German East African campaigns. His surveying background proved useful. He served on the South West Africa Boundary Commission at the end of 1915 and, in the following year, as an intelligence officer in Tanganyika, where he was struck with malaria, although this did not prevent him from surveying Saldanha Bay during the last half of 1917. Posted to Defence Headquarters at the end of 1917 to create an intelligence branch, Leipoldt served until his resignation from the UDF in $1924 .{ }^{120}$

Leipoldt would make two contributions to the official history programme: the first was a revision of the Wyndham manuscript, the second was main authorship of The Union of South Africa and the Great War, 1914-1918: Official History, which the General Staff published anonymously in 1924. Leipoldt was certainly an interesting choice. A land surveyor by profession he was unschooled in the historical method. He became the first of the official historians in South Africa not to have at least one degree in the liberal arts. While he may have been capable - something that Agar-Hamilton seems to have questioned ${ }^{121}-$ his appointment did create an unfortunate precedent. However, as mitigating circumstances, he not only spoke German, but had taught Military History and Tactics at the College and was, according to Collyer, 'in many ways specially fitted to do the work that is important from [a] General Staff point [of] view'. ${ }^{122}$

In November 1918, only days before the Armistice, Leipoldt was tasked by Collyer to write a brief history of the South West African campaign. A copy of the Wyndham manuscript was passed to him and he was specifically instructed to add material from the German military archives, which had been unavailable to Wyndham in 1916, but had since become accessible in Windhoek. ${ }^{123}$ These archives included the records of the German General Staff in Windhoek - which had already been used by a protégé of Colonel Franke, the former German commander, in the writing of a history of the South West campaign 
from a German point of view ${ }^{124}$ - as well as the records of the South African wartime units which had been or were about to be disbanded.

Leipoldt also convinced his superiors that an assistant was essential and a Citizen Force officer, Captain MSJC van Tijen, ${ }^{125}$ was placed at his disposal. Van Tijen, an amateur historian, was tasked to trawl the records of the units disbanding in Cape Town as well as the records Leipoldt had lodged there in $1915 .{ }^{126}$ But he seems to have had time for his own work too, for Van Tijen, during the course of 1919, translated the diaries kept by Lettow-Vorbeck during the East African campaign, from the original German into English. This he completed in South Africa in 1920, and the translated manuscript was handed to the War Office in April of that year and subsequently published as P.E. von Lettow-Vorbeck, My Reminiscences of East Africa. ${ }^{127}$

Yet, despite the small successes, all did not auger well. Earlier in his career, Leipoldt had made an enemy of Howard Gorges, who in October 1915 became the first civilian administrator of the territory of South West Africa. Gorges now made Leipoldt's visit to Windhoek difficult. ${ }^{128}$ Collyer, and then Smuts, interceded before work could continue. ${ }^{129}$ However, there were other problems. The force commanders in South West had not submitted regular despatches and, while the war diaries for the Central and Northern forces were deemed satisfactory, there were none from the Southern and Eastern forces, despite repeated reminders through 1915. General Jaap van Deventer, the commander of Southern Force, stated in May 1915 that he had 'sufficient notes from which [to] compile [a] Diary of his force later.' ${ }^{130}$ Wyndham had first encountered this record shambles in late 1916, something that seems to have spurred Bourne to promote improved record keeping and the creation of a military archival organisation.

Leipoldt's manuscript was completed toward the end of 1919: Smuts saw it on 4 November, it was circulated for comment, signed off by Collyer and Andries Brink, his successor as chief of the general staff, and finally approved by Hendrik Mentz, the new defence minister, for despatch to the War Office on 6 October 1920. ${ }^{131}$ This typed document was titled "Historical Record of the campaign in German South West Africa" and a limited number were produced: one copy went to Smuts, six to the war office, one to the Military School, and one to New Zealand. ${ }^{132}$ One copy also found its ways into the DC archives. It is an interesting document comprising 56 pages of text and tables supplemented by ten maps. Writing to Collyer in August 1919, Leipoldt expressed his intent: 'In attempting to write a short history of the South West African Campaign it has been endeavoured to indicate as concisely as possible the important events and results of the campaign and the means whereby they were achieved, what has been done and how it was done.' He went on:

To deviate on any intentions that never materialised or on operations not directly contributing to important results, will obviously be devoid of interest to the War Office for whom I understand this work is in the first instance intended. As the War Office Authorities will for some time to come be very occupied with historical data of the many other campaigns of the war the work has been arranged so as by diagrams to convey the important events with the minimum of study to a soldier. Volumes may be written on each of the subjects to which a brief chapter only is devoted here, but it may be of interest to the people of South Africa and perhaps of profit to the Government, to publish a more detailed and popular version of the operations that made South African achievements unique in military history. Such a work should be self-explanatory to the lay reader and should contain names of units, officers, killed and wounded. ${ }^{133}$

The 56 pages of the "Historical Record of the campaign in German South West Africa" make interesting reading. The work of several authors is noticeable. Leipoldt used Wyndham's manuscript, which he most probably shortened. He added a fresh layer of research, most-importantly the commander-inchief's despatches and the material from Windhoek. Several of the pages carry his initials at the bottom, 
suggesting that they were fine-tuned by him from the original Wyndham manuscript or after circulation within the general staff.

This draft of the official history omitted Sandfontein and the events of 1914 altogether. Referring to the Rebellion, Leipoldt first argued that the operations before early January 1915 were simply 'military expedients to meet various emergencies as they arose and [did] not [form] part of any co-ordinated plan of campaign against South West Africa'. Second, he felt it would 'not be doing justice to the military enterprise of the Union of South Africa to consider or refer to any military incident in South West before January 1915 [as] these operations [could] only be appreciated and viewed in their proper perspective when treated as a complete history of military events in South Africa in 1914', which, he added, was 'not the purpose' of the history being writing. ${ }^{134}$ These views did not accord with sentiment at Defence Headquarters and the opening paragraphs are struck through with a heavy, charcoal pencil, possibly by Smuts, more likely by Collyer.

\subsection{Widening the lens: The Union of South Africa and the Great War: Official History}

In the meantime, the government had moved forward with the idea of producing a more encompassing, popular history of South Africa's contribution to the First World War. The "Historical Record of the campaign in German South West Africa" and Buchan's work on the Infantry Brigade in France, which was published in 1920, covered only a small portion of South Africa's total war effort. Brigadier General Jack Collyer (1870-1941), who had informed the policy regarding an official history programme, and who had waited for so long to make his personal contribution in this regard, stepped forward in March 1920, when he broached the matter with Smuts. The official history programme would be extended.

Collyer, who was due to retire on 21 September, received a dual task. He was 'to write up the history and record of the Union's military effort during the war', and secondly 'prepare memoranda and notes on the various military problems of the Union which have to be considered and solved. ${ }^{135} \mathrm{He}$ would start with the first task. He estimated that the collection of source material would 'take ... some little time', but, importantly, that the historical narrative would be finished by the time he retired. But Collyer had learned from the earlier experiences of Wyndham and Leipoldt. He seemed to have settled on two conditions, namely that the heads of sections be instructed to furnish him with any records or information essential to him, and secondly that typing and clerical assistance be given. ${ }^{136}$

Collyer also had two questions for Smuts: one related to the scope of the work, the other to methodology and approach. Regarding the first, Smuts directed that a

complete account covering the whole of the Union's military effort throughout the period of the Great War, giving in some degree or detail the rebellion, the GSWA Campaign, the German East Africa Campaign (including central Africa) and the military measures taken in the Union, but also narrating in outline the composition, numbers and doings of the Overseas Contingents including Union troops sent to Egypt and Palestine, showing the operations in which they took part and giving some account of the principal engagements. ${ }^{137}$

Smuts wanted a fairly comprehensive account of the Union's military effort in all parts of the world and including all corps, contingents and units, including the various labour contingents. Collyer was specifically instructed that he could draw on Buchan for 'a good deal of useful material' on the Infantry Brigade on the Western Front, but that he had to address this campaign is such a way that the reader, wanting to understand how the Overseas Contingent was composed, how it was used and what it did, would not have to refer to Buchan. Collyer was to prepare this narrative for publication and public consumption. ${ }^{138}$ This meant that it had to be readable and avoid criticism. A fuller record, to be used for military and training purposes, would later contain a fuller criticism and record of the military reforms that transformed the Union Defence Force 
from the military constabulary it had been in August 1914 into an armed force of greater sophistication by 1918.

Collyer did not produce a manuscript. Either he had not progressed very far by the time of his retirement in September 1920, or he had written a narrative deemed unsuitable for the reading public. As a result, Leipoldt, who was transferred back to Defence Headquarters in February 1921 under instruction of Brigadier General Andries Brink, the new Chief of the General Staff, was now tasked with the writing 'up the (entire) history of the Union Troops in the War.' ${ }^{139}$ That Leipoldt met with Hendrik Mentz, the defence minister, to discuss the project in May 1921, is a clear indication of the importance the government still attached to the history of the armed forces and the role that this history might play in post-war South African society. ${ }^{140}$

The manuscript Leipoldt now produced, printed by the Government Printer in 1924 as The Union of South Africa and the Great War: Official History, remained for many decades the single attempt to write a comprehensive military history of the Union's contribution to the war effort. Published by the General Staff, this was a multi-authored work. Leipoldt used the German South West African campaign manuscript - penned sequentially by Wyndham in 1916/17 and then by himself in 1918/19 - as a basis. There is a close correlation between the "Historical Record of the campaign in German South West Africa" and chapter 2 (called Part II) of the Official History. Part II also contains useful statistics that are not found in the chapters for the other campaigns - this and the writing style indicate a different main author to the remainder of the Official History. It retains Wyndham's thumbprint as main author. Leipoldt was in all probability the main author for the rest, and second author for this Part II. Leipoldt probably also had access to whatever Collyer had written in 1920. To the sum of the above he added chapters on the other campaigns in which South African soldiers fought and drew from the secondary works available at the time, including Buchan's history of the South African brigade in France and the works on the Cape Corps written by Difford and Desmore. ${ }^{141}$ Leipoldt described the last as 'two very-well-written forerunners' of the impending flood of unit histories. A surveyor by profession, he added the maps. However, regardless of the number of pens involved, it is apparent that Leipoldt had done the lion's share of the work. ${ }^{142}$ Jan Ploeger came to a similar conclusion in 1989, although he did not present his evidence. However, in this way Leipoldt, although not a trained historian, made an invaluable contribution to South African military historiography: despite the opinion of a later official historian that the Official History had 'no outstanding merit. ${ }^{143}$ The Official History would remain the only book dealing with South Africa's entire war effort during the First World War until the appearance in 2007 of Bill Nasson's Springboks on the Somme.

The Union of South Africa and the Great War is in every respect an official history. Multi-authored, the text is heavy, wooden, and very matter-of-fact. Devoid of emotion and descriptive language it was perhaps the kind of neutral text the government wanted. Leipoldt highlighted the difficulties underlying the task in the preface. In the first instance, the contributions of the other dominions were comparatively homogenous and centralised on one or two fronts. For Australia, as example, this was largely Gallipoli and then the Western Front. Circumstances, however, 'directed South African activities into divergent channels that had little relation to each other. ${ }^{\text {'14 }}$ For the Union, operations had started against German South West Africa, but had to be suddenly suspended after the outbreak of the Rebellion. When the Rebellion was suppressed, operations very successfully restarted against GSWA, ending in July 1915. Two expeditionary forces were then sent, one to France (the $1^{\text {st }}$ SA Infantry Brigade), although it was temporarily diverted to Egypt, and the other to East Africa. But there were other units and formations in France - 2 heavy artillery brigades, a signal company, a railway company, an Auxiliary Horse Transport Company, the SANLC although these did not serve alongside the $1^{\text {st }}$ SA Infantry Brigade. A brigade of field artillery was sent to Egypt and Palestine, followed by the Cape Corps. Many joined the RAF and British regiments. Writing 
such a narrative, doing full justice to all of these detached undertakings was difficult, and particularly so if each event was placed in its context and relative historical importance.

As a result, much was omitted. The Union of South Africa and the Great War: Official History is not a popular biography or "who's who" of South Africans or of South African units that served during the war and is by no means a definitive work on South Africa in the war. In Leipoldt's words, and we may presume that he wrote the preface, 'The main purpose kept in view has been to record the effort and achievement of South Africa as a whole, bearing in mind the old adage "too many trees and one fails to see the wood". ${ }^{145}$ His was a general history and as such he could not do justice to 'all the detached undertakings if, at the same time, each event is to be kept in its correct position of relative historical importance' ${ }^{146} \mathrm{He}$ therefore does not follow and record the contribution of individual regiments and units to the warfighting on the various battlefronts. The main narrative follows the broad course of the war, making use of a conventional time division, and without slumping into the histories of all of the formations, regiments and units that served between 1914 and 1918, although short notes are included on the achievements of several units and formations: the SANLC, for example, has a single page in Part VIII Administration. Leipoldt and his principles were happy to leave this to the unit and regimental historians that would follow in the footsteps of Buchan, Difford and Desmore: the men of the SANLC, incidentally, would wait until 1987 for a unit history. ${ }^{147}$ Notwithstanding, The Union of South Africa and the Great War: Official History did not meet the expectation of several senior military officers. And it certainly did not get a firm nod from Brigadier General Jack Collyer, who still sought a detailed chronicle based on a utilitarian, "lessons learned" approach.

\subsection{John Collyer and the official histories of the African campaigns}

Collyer enjoyed a remarkably long career and gained a reputation among his underlings as 'a magnificent soldier ... with a brilliant and highly educated brain, coupled with a mordant sense of humour. ${ }^{148} \mathrm{He}$ began as a trooper in the Cape Mounted Riflemen and served on the Eastern Cape frontier in 1889 and later with the Pondoland Field Force, before gaining a commission during the Anglo-Boer War. His ability was recognised and promotion followed quickly within the Cape Colonial Forces - he was a major when he integrated into the UDF in 1912 - and, during the First World War, he served first as Botha's chief of staff in German South West and then served Smuts in the same capacity in German East Africa. He became the Union's first Chief of the General Staff in June 1917. Engaged briefly in 1920 on the Official History, Collyer retired later that year and devoted his retirement to the production of memoranda and his two primers on warfighting in Africa. Collyer, whom Smuts returned to harness in September 1939 as his military secretary, was described in 1941 as 'the Liddell Hart of South Africa. ${ }^{149} \mathrm{He}$ had, John Simpson proclaimed, 'the best military brain in the country apart from General Smuts. ${ }^{150}$

Importantly, once on the reserve list, Collyer could devote himself to the second of the two tasks allocated to him by Smuts in March 1920, namely 'to prepare memoranda and notes on the various military problems of the Union which have to be considered and solved. ${ }^{151}$ This it seems took two forms. Collyer was to produce memoranda, essentially documents that would inform policy, and contain comments and recommendations on specific points raised by the Minister of Defence. The first of these specific points related to the question of the Union assuming sole responsibility for the defences of the Cape Peninsula, in both peace and war, and the need for making Durban a defended port, and how an adequate garrison might be provided for both. ${ }^{152}$ The resolution of this question incidentally led in December 1921 to the withdrawal of the British garrisons and the closure of the South African Military Command. 
Secondly, and the primary focus of the second task, Collyer was to study the organisation and efficiency of the South African forces deployed between 1914 and 1918 for service in the First World War and prepare, not necessarily for publication, 'notes and criticisms' that might be used for military and training purposes. This work, Smuts ordered, had to 'be of a critical nature with a view to noting defects and recording suggestions for improvement and generally speaking be a work of military value for students and for the information and guidance of the Union and Imperial Governments and their military advisers from the point of view of co-operation with other forces in the large operations of war. ${ }^{153}$ With a few notable exceptions, the memoranda Collyer wrote have not been found. ${ }^{154}$ However, the approach suggested by Smuts, very utilitarian and fixed on military training and improved efficiency, imbued his subsequent books on South Africa's Great War African campaigns. And again Smuts's calculations made sense: Collyer had been in 'a first class position to observe the South African military machine at work, to know its strengths and weaknesses, to have first-hand experience of warfare both in desert and jungle' ${ }^{155}$ Who else was there, other than perhaps Smuts himself? But the master was busy with larger things.

In the meantime, in the United Kingdom the official war historians were studying the individual campaigns of the First World War in great detail and some of these focused on the extraction of so-called "lessons". ${ }^{156}$ In 1935 a number of chapters for a British version of the history of the German East African campaign arrived at General Headquarters in Pretoria. These chapters, forwarded by the History Section of the War Office to Smuts and Collyer and Colonel George Brink for comment, were written by Lieutenant Colonel Charles Horden and Major Henry Stacke and published in 1941, as Military Operations; East Africa as part of Britain's official History of the Great War series. ${ }^{157}$ The draft chapters met with criticism in 1935 and appear to have finally convinced Pretoria that a history of the German East African campaign, conducted from January 1916 under South African command, should also be written from a South African point of view. ${ }^{158}$ Of the official histories, only Buchan's work on France covered a separate campaign. The African campaigns - and Africa was the presumed theatre of future operations - were a glaring and significant gap in what was a rather ad hoc South African official history programme. The task of filling this gap devolved on Collyer.

In 1936, the Minister of Defence approached Collyer, now in his sixteenth year of retirement, to tackle the operational histories of the German South West and East Africa campaigns. A veteran of both campaigns, Collyer had always believed the job to be his. He had started on the German South West manuscript soon after his retirement in 1920, which he had intended to publish privately. ${ }^{159}$ But there was now pressing interest at General Headquarters and official sanction would bring its own rewards. Collyer was seemingly well underway by 1936 for the agreement between himself and the Department of Defence is dated 22 May 1936 and, on 6 June 1936, he submitted the first four draft chapters to General Andries Brink. A further two chapters were forwarded for comment on 15 June. Thereafter he submitted an average of three chapters every nine days.

The German South West campaign had special importance. It was the first operational deployment for a Union Expeditionary Force and, as such, provided the Union Defence Force with its first battle experience. It was, furthermore, as Collyer noted, 'the only land campaign undertaken, planned and brought to a conclusion by the military forces of any Dominion of the British Empire entirely on its own responsibility in the Great War. ${ }^{\text {'60 }}$ Of all the varied campaigns in which South Africans fought, this and East Africa seemed to hold the most relevance in terms of study by military officers and, indeed, Collyer's books on these two campaigns were to serve as textbooks at the Military College at Roberts Heights. His campaign histories - much to his delight, no doubt - were to have a utilitarian value, following in the spirit and initial intent of the British official history. ${ }^{161}$ In his introduction to The Campaign in German South 
West Africa, Collyer - like Major General "Boney" Fuller and other counterparts in the British Army ${ }^{162}$ stressed that:

We learn wisdom from failure much more than from success. We often discover what will do by finding out what will not do; and probably he who never made a mistake never made a discovery. ${ }^{163}$

This pointing out of "mistakes" was 'one, and perhaps the most important, of several motives' behind the writing of both books. ${ }^{164}$ Stated simply, the study of past campaigns it was hoped would enable armed forces to avoid similar mistakes, under comparable circumstances, in future.

The learning of "lessons" was "perhaps the most forcible, of several motives' that prompted the writing of this work. But there were other reasons too. There was the uniqueness of the German South West campaign, and the need for the rapid expansion of the Citizen Force during wartime - something South Africa would have to repeat on various occasions through the twentieth century. His second purpose therefore was to record 'the operation of a strategy based on a national system of tactics. ${ }^{165}$ The South West campaign had highlighted many important lessons. If attacked by a stronger power, South Africa would have to offset her technological inferiority by maximising the advantages offered by geography and the special aptitude of Union troops operating in familiar terrain. Technological weakness, Collyer argued, could be offset by the advantage of physical features and 'a system of defence which take full advantage of such natural support." ${ }^{166}$ Thirdly, he 'endeavoured to give some idea of the characteristics and methods of a great South African soldier whose example should always prove an inspiration to his fellow countrymen. ${ }^{167}$ After Botha arrived at Swakopmund, having undertaken a rapid wartime reform between September and December 1914, the operations in South West Africa were brief and uniformly successful. Here, as Collyer acknowledged, his books would assist in the construction of a Louis Botha narrative and the underlying nationbuilding imperative.

Like Wyndham and Leipoldt before him, Collyer battled with historical sources. He experienced a source hiatus in two respects. Firstly, he paused in the preface to lament the absence of war plans on the eve of the First World War, something he then dwelt on later in the main text. Secondly, he noted the failure of the commanders of the Central and Southern forces, and their staffs, to keep full records and furnish periodical dispatches to Defence Headquarters. Collyer, as Botha's chief of staff, served with the Northern Force and kept a record, which he could use for his book. As a result, there is more material on the Northern Force, and much less on the Central and Southern forces. This led inevitably to the more meagre account of the operations of two latter forces and a strong gradient in the text toward the Northern operations, which were in any case more decisive in terms of the wider campaign. Collyer noted in his preface that 'the official historian' - namely Leipoldt - also suffered from this paucity of information: in the Official History Leipoldt's account of fifty pages on the German South West campaign contains only two full pages and a few additional lines on the operations of the Southern and Central forces. But one thing is clear. Collyer worked in the more leisured 1920s and 1930s and, in retirement, should have had ample time to trawl the archives extensively. This he did not do, but limited his research it seems to his own private collection and a small supplement of dispatches.

Again, like his predecessors, Collyer had to obtain pre-publication approval for his manuscript from a board of senior officers, most of whom were veterans of the African campaigns. As such these men contributed to the narrative by filling in details and viewpoints not contained in the rather poor official record. General Andries Brink, the new Chief of the General Staff, in whose office Collyer's drafts were typed, informed him that '[s]hould any alterations be necessary in connection with your narrative of the Riet Pforte affairs, I will amend it from here. ${ }^{168}$ Colonel George Brink, another board member, suggested other amendments: 'I shall have to alter the account of the latter [Sandfontein] in the light of Welby's account'. ${ }^{169}$ This presented opportunity to further sanitise and emboss. 
Whereas Wyndham and Leipoldt had sidestepped the whole Sandfontein debacle, Collyer argued that, while this action 'was perhaps not of much importance since no more than a detachment was involved, and it had little influence on the campaign as a whole', 'it was a reverse and therefore [repaid] examination'. Like a rather old-fashioned headmaster, he highlighted a catalogue of errors, from 'the constant urging to press forward' from Defence Headquarters to the actions of Lukin. This was the warts-and-all approach Smuts had called for in 1920: the government had bungled politically, unnecessary risks had been taken, and serious questions had been raised about the preparedness of the military leadership and the efficiency of the UDF. Disaster was narrowly averted in 1914, following the defeat at Sandfontein and the outbreak of the Afrikaner rebellion. This seemed far from the nationbuilding goals of the Botha government and the creating some common feeling as 'South Africans'. ${ }^{170}$

Collyer's second work - the one inspired by the British official history - appeared in 1939 as The South Africans with General Smuts in German East Africa, 1916, some two years before the appearance Military Operations; East Africa. ${ }^{171}$ As the title indicated, this book dealt with the second phase of the campaign, with Smuts's advance from Taveta to the Rufiji River, and is very much in the tradition of the first. Again, broad, systematic explanation is circumscribed by a narrow, utilitarian approach. Collyer purposefully avoided the 'high politics, the broad principles of strategy, and operations and movements on a large scale [and] the statistical matter' found in many of the larger official histories, which he felt were of interest to the general historian, and of use to the military student with ample time at his disposal, but of little benefit to the younger military officer undergoing intensive, short spurts of training. Such an officer, 'compelled to learn his profession while he practices it', would benefit most Collyer argued from a more detailed, circumstantial study. ${ }^{172}$

Methodologically speaking not very innovative, Collyer's work nonetheless repays reading. They are tacit proof of South Africa's recognition of its imperial obligations during the interwar period. ${ }^{173}$ His twin volumes were the primers for warfighting in Africa, focussing on desert and jungle terrains. Aimed at instruction for officers at the Military College, he hoped his work would help prepare South African officers for service on 'the continent of Africa' ${ }^{174}$ Both books were prescribed at the college, although, from 1940, the exigencies of war, curtailed the reading lists. Officers being prepared once again for service in East Africa had to read Collyer's German East Africa, from page 260, the final chapter that summarised the nature of the "lessons" of the campaign, the need for pre-war preparation, the difficulty of strategic surprise, and the power of tactical defence. Very practically, having read Collyer, candidates were advised to acquire a "bush sense" and "make a friend of the bush". ${ }^{175}$ The focus, once on education, had devolved down to the lowest, technical level of training.

Despite its shortcomings, Smuts appeared pleased. The book he felt would be of interest to students of war but also to the general public. In his foreword, he praised Collyer for 'a careful critical study' and 'a very interesting and instructive account of the East African Campaign during the period covered by my command. ${ }^{176}$ But Smuts had learned much too. In 1940 he established a fully-fledged Union War Histories Section in the office of the prime minister and appointed Professor (later Colonel) John Agar-Hamilton, Leo Fouché's former deputy in the History Department at the University of Pretoria and an alumnus of Keble College, Oxford, to head the section. ${ }^{177}$ Professionalization would bring an increasing demand for "scientific" rigour in military-historical scholarship and a proliferation of such scholarship. In turn, over the ensuing decades, this imposed a complexity upon the historiography that served to overcome some traditional generalisations, and "lessons"-based arguments, and strengthen the view of the individuality of events. 


\section{Conclusion: new narratives and contested grounds}

The Botha government adopted a sequence of measures from September 1914 to satisfy the public demand for more news and for detailed accounts of recent military operations. A limited number of war correspondents were allowed on the battlefronts, a bureau was created to provide information and counsel to veterans, wives and widows, and in late 1914 of an official history programme was launched. But these three fields - the South African war correspondents, the General Information Bureau, and the official historians and their corpus of work written between 1914 and 1939 - are left largely unploughed by historians. The official history programme, which was tied from the start to the management of records in the UDF and contributed to the impetus behind the creation of a military archives in 1919, is the focus of this article.

Jan Smuts stands as a colossus on the South African landscape for much of the first half of the twentieth century. That he played a cardinal role in foundation the official history programme in South Africa and in the selection of the first official historians should come as no surprise. Smuts was, Richard Steyn reminds us, 'eager to apply his intellect and energy to the creation of a new country' ${ }^{178}$ and, no matter how reluctant he may have been to trust less capable subordinates, he recognised the importance of the Great War and its historiography in terms of the government's nationbuilding programme. $\mathrm{He}$ decided what would be written, how it would be written, and who would do the writing.

The writing of the history of South Africa's Great War was no straightforward task. The efforts made by the official historians proved neither simple nor uncontroversial. Conducted in fits and starts the fledgling UDF had no "historical section" - the programme remained largely ad hoc, shaped by political forces, the flow of the war, and the whims of a succession of senior military officers. Their task was made more difficult by the complex series of divergent campaigns in which South Africans fought. Yet, while the difficult spatial limits escaped simple chronological narrative, there were other questions too. The best official, wartime history according to British military historian, Sir John Keegan, attempt objectivity: while they put 'the best face on things, they tell no lies and admit a good deal of the truth. ${ }^{179}$ There is always a balance between producing a credible narrative for the public and the concealment of any suggestion of personal incompetence, of disputes over strategy or tactics, or of differences in approach between allies within the wider context of the war. Official historians, in this sense, are instruments of government, guided by policy, and during wartime seek to enhance a feeling of crossclass solidarity within the nation and cooperation within the alliance. They are, simply stated, instruments of nationbuilding, and often so at particularly critical times.

Five official historians were appointed in South Africa. One was a professor of history (Fouché) and four were military officers (Wyndham, Buchan, Leipoldt and Collyer): two Afrikaans, three English-speakers. Fouché, the only civilian in the group, wrote two narratives on the Afrikaner Rebellion, both were largely political history and were published as government blue books in 1915 and 1916. Wyndham produced the first draft on the German South West Africa campaign (1916-17), which was revised by Leipoldt (1918-19), and then subsumed into The Union of South Africa and the Great War: Official History (1924), of which Leipoldt was the primary author. The remaining campaign histories were produced by Buchan in 1920 (the Springboks on the Western Front) and Collyer in 1937 (German South West) and 1939 (German East Africa). Gratifyingly, despite Collyer's reservations, a scholarly education seems to have been a requirement: Fouché was a professor of history and Buchan and Wyndham, both citizen soldiers, had studied History and the Classics at Oxford. Smuts must have tempered Collyer's views. The Second World War broke out in the year that Collyer published his second book and, in 1940, Smuts, once again in power, established the Union War Histories Section as a fully-fledged history section in the office of the prime minister. 
Today, one hundred years on, the significance of the First World War to the foundation of South African society is again being questioned. Unlike the United Kingdom and Australia and the other 'settlement dominions', the First World War is not a powerful source of national identity in South Africa. Although popular South African remembrance and commemoration of the war began with the wartime propaganda and the subsequent official history programme, and a certain amount of mythmaking, the Armed Struggle and the War for Southern Africa (1961-1989) is proving more significant to national consciousness, inspiring in turn a new catalogue of myths and legends. However, the passage of time, the generation of new histories and narratives, and the construction (both meanings) of Freedom Park outside Pretoria from 2005, and the government campaign since 1994 to create a Mendi site of memory, has reintroduced the First World War, although on a limited front, to the foundation narrative.

One of the themes of the new historiography of South Africa's Great War has been to emphasize the point that the historical memory of exploitation and resistance to colonial rule has been a prime ingredient in African nationalism. Where the heroes of the first, official histories were Botha and Smuts, Van Deventer, Crewe and Brits, Lukin, Dawson and Tanner, those of a New South African memory are the men of the SANLC, Isaac Dyobha, and the 615 black men who drowned when the Mendi sank on 9 March 1917. Military service and sacrifice is no longer expressed in terms of the battlefield successes and losses, but rather the loss of a largely anonymous contingent of black men pressed into labour battalions by callous governments in Pretoria and London. Recognition of this has led to a reorientation in the South African memorial at Delville Wood and the growth of an alternate Mendi myth, with the controversy that will accompany it. "History" is in a constant state of rebirth and in South Africa, as elsewhere, the Great War represents a "contested ground" and will continue to evoke new meanings and shift sites of memory.

\section{ABBREVIATIONS}

John Buchan papers - John Buchan fonds 2210, Queens University Archives, Kingston, Ontario.

HHA - Hagley Hall Archives, Hagley, West Midlands

NASA - The National Archives of South Africa, Pretoria

PHA - Hugh and Maud Wyndham papers, Petworth House Archives

SANDF Documentation Centre - Department of Defence Archives, SANDF Documentation Centre, Pretoria

TNA - The National Archives of the United kingdom, Kew

UPA - United Party Archives, University of South Africa, Pretoria

Wits - William Cullen Library, University of the Witwatersrand

WSRO - West Sussex Record Office, Chichester

\section{NOTES}

Maud Wyndham, Johannesburg, to Lady Leconfield, 25 May 1920, PHA, WSRO.

Ian van der Waag, 'Wyndhams, Parktown, 1901-1923: Domesticity and Servitude in an early twentiethcentury South African Household', Journal of Family History, vol 32, no 3, July 2007, pp 259-95. Maud Wyndham was born a Lyttelton and there is a substantial holding of letters in the Hagley Hall Archives (HHA) in the West Midlands and in the Petworth House Archives (PHA) in West Sussex.

For a good introduction to official history and the nature of official history programmes following the two world wars see Jeffrey Grey, ed., The Last Word? Essays on Official History in the United States and British Commonwealth (Praeger, Westport, Connecticut and London, 2003).

The numbers are made up as follows: 146897 whites, 25000 coloureds and Indians, and 82769 blacks. Bill Nasson, Springboks on the Somme; South Africa in the Great War, 1914-1918 (Penguin, Johannesburg, 2007), pp 10-11. 
See for example William Carter to Algernon Lawley, 6 Aug 1914, AB186 Archbishop Carter Letters, Wits. Maud Wyndham to Lady Leconfield, 11 Aug 1914, PHA, WSRO.

Ian van der Waag, 'The battle of Sandfontein, 26 September 1914; South Africa, military reform and the German South West Africa campaign, 1914-15', First World War Studies, vol 4, no 2, 2013, pp 141-65. Allister Sparks, First Drafts; South African History in the Making (Jonathan Ball Publishers, Johannesburg and Cape Town, 2009), p xi.

For the positon in the United Kingdom see Lord Riddell, War Diary, 1914-1918 (Ivor Nicholson \& Watson, London, 1933), pp 16-21.

Robin Higham, ed., Official histories: Essays and bibliographies from around the world (Kansas University Press, Kansas, 1970), p 1.

Jan Ploeger, 'Suid-Afrikaanse staats- en staatsondersteunde militêre geskiedskrywing, 1924-1987', Militaria, vol 19, no 4, 1989, pp 15-36.

Jan Ploeger and Ian van der Waag, 'South African State and State-Sponsored Military Historical Research, 1924-1995', in Robin Higham, ed., Official Military Historical Offices and Sources; Volume 1: Europe, Africa, the Middle East and India (Greenwood Press, Westport, Connecticut and London, 2000), pp 261-88.

Ian van der Waag, 'Contested Histories: Official History and the South African Military in the Twentieth Century', in Jeffrey Grey, ed., The Last Word? Essays on Official History in the United States and British Commonwealth (Praeger, Westport, Connecticut and London, 2003), pp 27-52.

Bill Nasson, Springboks on the Somme; South Africa in the Great War, 1914-1918 (Penguin, Johannesburg, 2007), chapter 9.

Tim Cook, Clio's Warriors; Canadian historians and the writing of the world wars (UBC Press, Vancouver and Toronto, 2006). Jenny Macleod, Reconsidering Gallipoli (Manchester University Press, Manchester and New York, 2004). Mesut Uyar, 'Remembering the Gallipoli campaign: Turkish official military historiography, war memorials and contested ground', First World War Studies, pp 1-27, online: 22 Sep 2016. I gratefully acknowledge their valuable insights, which have influenced this article.

Archive of the General Information Bureau (GIB), box 1, file B.1 General Information Bureau, SANDF Documentation Centre. E Jonker, 'Die Militêr-Historiese en Argivale Dienste van die Departmenet van Verdediging', Militaria, vol 1, no 1, 1969, p 4.

Special report on system for Chief of the General Staff and Adjutant General, archive of the Officer in Charge of Records (OC Records), box 92, file OR133/2 Working of Record Offices, SANDF Documentation Centre.

OC Records, box 101, file OR143/2 Notification of Branch Record Office, SANDF Documentation Centre. OC Records, box 102, file OR143/14 Transferring of Brand Record Office to Dar-es-Salaam, SANDF Documentation Centre.

OC Records, box 102, file OR143/13 Cessation of Hostilities British East Africa Winding up of Records, SANDF Documentation Centre.

Staff Officer for War Recruiting to the OC Records, 20 Dec 1917, OC Records, box 109, file OR185 Historical Records SA Imperial Service Units, SANDF Documentation Centre. This was the start of the Unit Histories element of the SANDF Documentation Centre.

Basden was a well-known philatelist. His Transvaal Postage Stamps was published by the Royal Philatelic Society in London in 1940.

Chief Clerk Defence to Secretary for Defence, 26 Nov 1918, DC, box 1909, file DC251/1 Records Amalgamation of War Records, SADF Documentation Centre.

Circular minute DC $1 / 50350$ of 6 Jan 1919, DC, box 882, file 23479 War Records, SANDF Documentation Centre.

DC, box 1909, file DC 251/1 Records Amalgamation of War Records, SANDF Documentation Centre. GH Byrnes to Chief Clerk Defence, 17 Sep 1919, DC, box 1909, file DC 251/1 Records Amalgamation of War Records, SANDF Documentation Centre. Circular minute DC 9/50350 of 1 Oct 1919, DC, box 882, file 23479 War Records, SANDF Documentation Centre.

For a discussion of this process see Ian van der Waag, 'The Marriage of Clio and Mars: The practice of military history within the South Africa Defence Force, 1912-1992' (Directorate Documentation Service, Pretoria, 1992), pp 14-29, and Ian van der Waag, 'Military Record Preservation in South Africa, 19141992; a history of Directorate Documentation Service', Militaria, vol 23, no 4, 1993, pp 16-31.

The records of the SA Veterinary Corps and the Water Supply Corps are cases in point. SO Veterinary Service to the Quartermaster General, 19 Nov 1919, DC, box 882, file 23479 War Records; and Director of Irrigation to the Quartermaster General, 17 Jan 1919, DC, box 878, file 23282 Historical Records of South African Imperial Service, SANDF Documentation Centre. 
On 1 July 1920 the offices of the Custodian of War Records (Defence Secretariat) and the Staff Officer War Registers (previously OC Records, General Staff Section) were amalgamated to form the office of the Staff Officer War Records and on 11 October 1921 this office was transferred to the Adjutant General's Section. DSO No 1 Military District to Adjutant General, 5 Sep 1919, DC, Box 1909, file DC 251/1 Records Amalgamation of War Records, SANDF Documentation Centre.

Deputy Commissioner of Police (Grahamstown) to the Secretary, SA Police, 20 Apr 1921, and Quartermaster General to the Inspector General, Permanent Force, 11 May 1921, DC, Box 882, file 23479 War Records, SANDF Documentation Centre. Some of the files destroyed were needed a year later. See Staff Officer War Records to Chief Clerk Defence, 4 Oct 1922, archive of the Chief of Defence Force Administration (HWA 668), Box 1, file HWA 668/2/1 Organisasie Beleid, SANDF Documentation Centre.

Deputy Assistant Adjutant General to the SO War Records, 18 Dec 1921, DC, Box 1909, file DC 251/1 Records Amalgamation of War Records, SANDF Documentation Centre.

Chief Clerk Defence to SO War Records, 12 Oct 1920, and Secretary of Defence to Commissioner of Enemy Subjects, 22 Oct 1920, DC, Box 1909, file DC 251/1 Records Amalgamation of War Records, SANDF Documentation Centre.

DC, Box 1911, file DC 251/8 Records of Native and Coloured Sections of South African Forces, Transfer of Records from native Affairs Department to OC Records Office, SANDF Documentation Centre.

Staff Officer Veterinary Service to Quartermaster General, 19 Nov 1919, DC, Box 882, file 23479 War Records, SANDF Documentation Centre.

Director of Irrigation to the Quartermaster General, 17 Jan 1919, DC, Box 878, file 23282 Historical Records of South African Imperial Service, SANDF Documentation Centre.

Thomas Fisher Unwin to WP Schreiner, 22 Dec 1914, DC, Box 189, file 11122 Correspondence with various people re History of the German South West African Campaign, SANDF Documentation Centre.

Ministers' Minute, 19 Aug 1915, DC, Box 189, file 11122 Correspondence with various people re History of the German South West African Campaign, SANDF Documentation Centre.

Rodney Warwick, 'The Battle of Sandfontein: The role and legacy of Major-General Sir Henry Timson Lukin', Scientia Militaria, vol 34, no 2, 2006, p 86.

WS Rayner (with WW O'Shaughnessy), How Botha and Smuts Conquered German South West (Simpkin, Marshall, Hamilton, Kent \& Co. Ltd, Stationers' Hall Court, London, 1915); and JP Kay Robinson, With Botha's Army (George Allen \& Unwin, London, 1916).

Taylor Downing, Secret Warriors; Key Scientists, Code Breakers and Propagandists of the Great War (Little Brown, London, 2014), pp 283-84, 318-20.

Worthy of mention are W Whittall, With Botha and Smuts in Africa (Cassell and Company, London, 1917); and HF Trew, Botha Treks (Blackie \& Son, London and Glasgow, 1936).

In Robinson's case, Louis Botha provided a frontispiece in which he praised Robinson for the 'able and good description of the fine spirit which animated our army in German South-West Africa, and of the good humour which kept our men cheerful under most trying conditions.' Louis Botha to Robinson, 24 Nov 1915, frontispiece to JP Kay Robinson, With Botha's Army (George Allen \& Unwin, London, 1916). Other notable contributions in this genre of war literature are Major PJ Pretorius, Jungle Man (George G Harrap, London, 1947), Major General Sir KR van der Spuy, Chasing the Wind (Books of Africa, Cape Town, 1966), and Piet van der Byl, From Playgrounds to Battlefields (Howard Timmins, Cape Town, 1971). To these should be added the corpus of rebellion literature, including General JCG Kemp, Die Pad van die Veroweraar (Nasionale Pers, Kaapstad, 1946).

Col JJ Collyer to Secretary for Defence, 18 Aug 1915, DC, Box 189, file 11122 Correspondence with various people re History of the German South West African Campaign, SANDF Documentation Centre.

Col JJ Collyer to Secretary for Defence, 18 Aug 1915, DC, Box 189, file 11122 Correspondence with various people re History of the German South West African Campaign, SANDF Documentation Centre.

Secretary for Defence to J.K. Robinson, 19 Aug 1915, DC, Box 189, file 11122 Correspondence with various people re History of the German South West African Campaign, SANDF Documentation Centre.

JP Kay Robinson, With Botha's Army (George Allen \& Unwin, London, 1916), p 12.

Bourne to Buchan, 25 Mar 1920, box 3 correspondence general, John Buchan papers.

FA Mouton, 'Professor Leo Fouché, the History Department and the Afrikanerization of the University of Pretoria', Historia, vol 38, no 1, May 1993, pp 51-63; and Albert Grundlingh, 'Politics, Principles and Problems of a Profession: Afrikaner historians and their discipline, c.1920-c.1965', History Workshop, vol 149, Feb 1990, p 6.

Patrick Duncan to Howard Pim, 9 Mar 1915, A881 Pim Papers, BL.1, Wits.

Lord Selborne to Howard Pim, 3 Mar 1915, A881 Pim Papers, BL.1, Wits; and South African Parliamentary Papers: UG 10/1915. Report on the outbreak of the rebellion and the policy of the government with regard to its suppression. 
As quoted in FA Mouton, 'Professor Leo Fouché, the History Department and the Afrikanerization of the University of Pretoria', Historia, vol 38, no 1, May 1993, p 54.

As quoted by FA van Jaarsveld, Afrikanergeskiedskrywing: Verlede, Hede en Toekoms (Lex Patria, Pretoria, 1992), p 46.

Bourne to Gorges, 9 Oct 1915, A103 Rebellion, Wits.

Bourne to Fouché, 18 Oct 1915, A103 Rebellion, Wits.

Bourne to Gorges, 9 Oct 1915, A103 Rebellion, Wits.

Gorges to Bourne, 10 Oct 1915, A103 Rebellion, Wits.

See CAB 44/2 Operations in the Union of South Africa and German South West Africa, TNA.

Diverse, Box 1, file D823/9199 Writing of History of the rebellion by Professor Fouché, SANDF Documentation Centre.

HN Richardson, Admiral's Office, Simon's Town to Bourne, 4 Nov 1916, DC, Box 779, file D.B.2338/9199 Official History of GSWA Campaign, SANDF Documentation Centre.

JJ Collyer to Secretary for Defence, 18 Aug 1915, DC, Box 189, file 11122 Correspondence with various people re History of the German South West African Campaign, SANDF Documentation Centre.

Acting Adjutant General to Brig Gen JJ Collyer, 19 Jul 1916, DC, Box 189, file 11122 Correspondence with various people re History of the German South West African Campaign, SANDF Documentation Centre.

This mounted regiment was first known as the Eastern Rifles, until amalgamation with the Western Rifles and a name change in 1907. Ian van der Waag, 'Rural struggles and the politics of a colonial command: The Southern Mounted Rifles of the Transvaal Volunteers, 1905-1912', in Stephen Miller, ed., Soldiers and Settlers in Africa, 1850-1918 (Brill, Leiden, 2009), 251-285.

Maud Wyndham to Lady Leconfield, 15 Jul 1915, PHA, WSRO. See also Edward Wyndham to Mary Maxse, 22 Jun 1915, Maxse Papers 455, WSRO. Hugh Wyndham to Lady Leconfield, 9 Sep 1915 and 22 Sep 1915, PHA, WSRO.

Ian van der Waag, 'Hugh Archibald Wyndham; His life and times in South Africa, 1901-1923' (DPhil dissertation, University of Cape Town, 2005).

Secretary for Defence to Wyndham, 6 Nov 1916, Personnel Archives and Reserves (PAR), file 196 Lt Col Hon HA Wyndham (hereafter Wyndhams' personnel file), SANDF Documentation Centre.

Bourne to Smuts, 2 Nov 1916, DC, Box 779, file 2338/9199 Official History of GSWA Campaign, SANDF Documentation Centre.

Hugh Wyndham to Lady Leconfield, 17 Nov 1916, PHA, WSRO.

Hugh Wyndham to Lady Leconfield, 10 Dec 1916, PHA, WSRO.

Hugh Wyndham to Lady Leconfield, 17 Nov 1916, WSRO: PHA. See also Hugh Wyndham to Lady Leconfield, 25 Nov 1916, PHA, WSRO.

Maud Wyndham to Lady Leconfield, 11 Dec 1916, PHA, WSRO.

JC Smuts to Roland Bourne, 3 Nov 1916, and Roland Bourne to Hugh Wyndham, 6 Nov 1916, DC, Box 779, file 2338/9199 Official History of GSWA Campaign, SANDF Documentation Centre.

See for example SAMR, Box 1044, file 516/89 War History of GSW Campaign being written by Col the Hon H Wyndham, SANDF Documentation Centre.

Maud Wyndham to Lady Leconfield, 12 Nov 1916, PHA, WSRO.

DC, Box 779, file D.B.2338/9199 Official History of GSWA Campaign, SANDF Documentation Centre. [The case concerns reports held by the Director of Mechanical Transport.]

Bourne to Collyer Morogoro, 28 Nov 1916, and Collyer Morogoro to Bourne, 29 Nov 1916, DC, Box 779, file D.B.2338/9199 Official History of GSWA Campaign, SANDF Documentation Centre.

Hugh Wyndham to Lady Leconfield, 21 Jun 1917, PHA, WSRO.

Hugh Wyndham to Lady Leconfield, 25 Nov 1916, PHA, WSRO.

Hugh Wyndham to Lady Leconfield, 21 Jun 1917, PHA, WSRO.

JC Smuts to Lady Leconfield, 7 May 1917, PHA 9579, WSRO; and Maud Wyndham to Lady Leconfield, 22 Jun 1917, PHA, WSRO.

Maud Wyndham to Lady Leconfield, 1 Jul 1917, PHA, WSRO. See also Maud Wyndham to Lady Leconfield, 22 Jun 1917, PHA, WSRO.

JX Merriman to Lord Buxton, 5 Dec 1916, in Phyllis Lewsen, ed., Selections from the Correspondence of JX Merriman (Van Riebeeck Society, Cape Town, 1969), pp 285-86.

Hugh Wyndham to Lady Leconfield, 25 Nov 1916, 10 Dec 1916, PHA, WSRO.

Hugh Wyndham to Lady Leconfield, 17 Feb 1915, PHA, WSRO.

See SAMR, Box 1044, file 516/89 War History of GSW Campaign being written by Col the Hon H Wyndham, SANDF Documentation Centre.

Buchan to his mother, 3 Nov 1899, box 1, file 5, correspondence general, John Buchan papers.

AJ Butler to Buchan, 5 Nov 1899, box 1, file 5, correspondence general. John Buchan papers. 
JA Smith, John Buchan; A Biography (Rupert Hart-Davis, London, 1965), p 165. Buchan to his mother, 13 Sep 1901, box 1, file 5, correspondence general, John Buchan papers. See also K Grieves, 'Nelson's History of the War: John Buchan as a Contemporary Military Historian, 1915-1922', Journal of Contemporary History, vol 28, no 2, 1993, p 545.

Buchan to his mother, 9 Aug 1901, box 1, file 5, correspondence general, John Buchan papers.

Taylor Downing, Secret Warriors; Key Scientists, Code Breakers and Propagandists of the Great War (Little Brown, London, 2014), p 287.

Buchan to John Edgar, Cairo, 28 March 1916, box 2, correspondence general, John Buchan papers.

Margot Asquith to Buchan, 11 May 1916, box 2 correspondence general, John Buchan papers. Smuts to Buchan, 7 Jan 1919, box 3 correspondence general, John Buchan papers.

FS Oliver to Buchan, 8 Feb 1917, box 3, correspondence general, John Buchan papers.

David Lloyd George, War Memoirs of David Lloyd George, vol III (London, 1934), pp 1492-1493.

JA Smith, John Buchan; A Biography, p 230; and B.H. Liddell Hart, The Memoirs of Captain Liddell Hart, I (Cassell, London, 1965), pp 363-364.

K Grieves, 'Nelson's History of the War: John Buchan as a Contemporary Military Historian, 19151922', Journal of Contemporary History, vol 28, no 2, 1993, p 533. See also Peter Buitenhuis, The Great War of Words: Literature as Propaganda 1914-18 and After (BT Batsford, London, 1989).

Buchan to Basil Liddell Hart, 13 Jan 1917, Liddell Hart mss. 1/124/2, Liddell Hart Centre for Military Archives, KCL, as quoted by K Grieves, 'Nelson's History of the War: John Buchan as a Contemporary Military Historian, 1915-1922', Journal of Contemporary History, vol 28, no 2, 1993, p 541.

Britten Austin to Buchan, 19 Nov 1917, box 3 correspondence general, John Buchan papers.

Smuts to Buchan, 7 Jan 1919, box 3 correspondence general, John Buchan papers.

Preface to Buchan, The History of the South African Forces in France (Battery Press, Nashville, 1992).

Nasson, Springboks on the Somme, p 207. See also Introduction by Dr GM Bayliss, to Buchan, South African Forces in France.

Buchan, South African Forces in France, p 192.

Buchan, South African Forces in France, p 258.

This is perhaps most strong in Australia with creation of the "Anzac Legend". See Jenny Macleod, Reconsidering Gallipoli, pp 4-15.

On 19 Jul 1917, the first Delville Wood Day, John X Merriman, South Africa's senior statesman, likened Delville Wood to South Africa's Thermopylae, her Mortgarten. 'Union's Roll of Honour. Deathless Deeds at Delville Wood. Musical Memorial Service in the City Hall. Mr Merriman on South Africa's Heritage', Cape Times, 19 Jul 1917, p 6. See also, Programme, Delville Wood Day, PM 1/1/48, file 4/84/1917 European War, SA Brigade Successes, NASA.

Bill Nasson, History Matters; Selected Writings, 1970-2016 (Penguin, Cape Town, 2016), p 92.

George Trevelyan to Buchan, 23 Mar 1920, box 3 correspondence general, John Buchan papers.

Buxton to Buchan, 19 Apr 1920, box 3 correspondence general, John Buchan papers.

HT Lukin to Buchan, 24 Feb 1920, box 3 correspondence general, John Buchan papers.

Brig Gen AJE Brink to Buchan, 16 March 1920, box 3 correspondence general, John Buchan papers.

Brig Gen SF Thackeray to Buchan, 14 Dec 1920, box 3 correspondence general, John Buchan papers.

Tanner to Buchan, 16 Mar 1920, box 3 correspondence general, John Buchan papers.

Sir Roland Bourne to Buchan, 25 Mar 1920, box 3 correspondence general, John Buchan papers.

Sir Roland Bourne to Buchan, 25 Mar 1920, box 3 correspondence general, John Buchan papers.

Buchan, South African Forces in France, p 11.

C Louis Leipoldt, Bushveld Doctor (Jonathan Cape, Johannesburg, 1937), p 51.

JGW Leipoldt, 'Notes on the Steinkopf beds of Namaqualand', Transactions of the Geological Society of South Africa, 1911, pp 20-23; 'Errors of the Parallel-Plate Micrometer', Survey Review, 1913; and 'Observing with the Zeiss and Wild Theodolites', Empire Survey Review, vol 4, no 26, 1937, pp 206-13. Piet van der Byl, From Playgrounds to Battlefields (Howard Timmins, Cape Town, 1971), p 145.

Maurits to Beyers, 8 June 1914, f.99, A.414 General CF Beyers Collection, NASAP.

Ian van der Waag, 'Major JGW Leipoldt, DSO; a portrait of a South African surveyor and intelligence officer, 1912-1923', Militaria, vol 25, no 1, 1995, pp 12-34.

JAI Agar-Hamilton, 'The Union of South Africa War Histories' in Robin Higham (ed), Official Histories; Essays and Bibliographies from around the World, p. 443.

Collyer to Hirsch, 4 Feb 1919, PAR, Leipoldt's personnel file, SANDF Documentation Centre.

Leipoldt to Collyer, 9 Nov 1918, DC, Box 364, file 40185 German Military Records, SANDF Documentation Centre.

DC, Box 364, file 40185 German Military Records, SANDF Documentation Centre; and R. Hennig, Deutsch-Südwest im Weltkriege (Verlag Süsseroth, Berlin, 1920) and Hans von Oelhafen, Der Feldzug in Südwest, 1914-15 (Safari-Verlag, Berlin, 1923). 
DC, Box 422, file 51204 Translation Von Lettow's Diary, SANDF Documentation Centre. Leipoldt to Chief of Staff, 28 Jan 1919, PAR, file P1/A17963 Major JGW Leipoldt, DSO Permanent Force (Staff) Intelligence (hereafter Leipoldt's personnel file), SANDF Documentation Centre.

Hurst and Blackett, London, 1920.

For the background to this difficult relationship see I van der Waag, 'Major JGW Leipoldt, DSO; a portrait of a South African surveyor and intelligence officer, 1912-1923', pp 12-34.

Collyer to Hirsch, 4 Feb 1919, and Collyer to Deputy Chief of the General Staff, 11 Feb 1919, PAR, Leipoldt's personnel file, SANDF Documentation Centre.

Destaf to Defence, 14 May 1915, DC, Group 2, Box 252, file South West African Campaign History, SANDF Documentation Centre.

Chief of the General Staff to Secretary for Defence, 9 Oct 1920, DC, Group 2, Box 252, file South West African Campaign History, SANDF Documentation Centre.

Handwritten note on Ministers' Minute, 26 Oct 1920, DC, Group 2, Box 252, file South West African Campaign History, SANDF Documentation Centre.

Major JGW Leipoldt to Chief of the General Staff, 13 Aug 1919, DC, Group 2, Box 252, file South West African Campaign History, SANDF Documentation Centre.

"Historical Record of the Campaign in German South West Africa", DC, Group 2, Box 252, file South West African Campaign History, SANDF Documentation Centre. Leipoldt was the last author on this manuscript, although it carried much from Wyndham's pen. Ian van der Waag, 'The battle of Sandfontein, 26 September 1914; South Africa, military reform and the German South West Africa campaign, 1914-15', First World War Studies, vol 4, no 2, 2013, p 152.

Brig Gen Collyer to Secretary for Defence, 25 Mar 1920, Personnel file Maj Gen JJ Collyer, Personnel Archives and Reserves, SANDF Documentation Centre.

Brig Gen Collyer to Secretary for Defence, 25 Mar 1920, Personnel file Maj Gen JJ Collyer, Personnel Archives and Reserves, SANDF Documentation Centre.

Secretary for Defence to Brig Gen JJ Collyer, 30 Mar 1920, Personnel file Maj Gen JJ Collyer, Personnel Archives and Reserves, SANDF Documentation Centre.

Secretary for Defence to Brig Gen JJ Collyer, 30 Mar 1920, Personnel file Maj Gen JJ Collyer, Personnel Archives and Reserves, SANDF Documentation Centre.

Jordan to Armour, 21 Mar 1921, PAR, Leipoldt's personnel file, SANDF Documentation Centre.

Minister of Defence to Chief of the General Staff, 6 May 1921, and Dechief to Minister of Defence, 6 May 1921, PAR, Leipoldt's personnel file, SANDF Documentation Centre.

Captain Ivor D Difford, The Story of the 1st Cape Corps, 1915-1919 (Hortors, Cape town, 1920) and AJB Desmore, With the 2nd Cape Corps thro' Central Africa (Citadel Press, Cape Town, 1920).

J Ploeger, 'Suid-Afrikaanse Staats- en Staatsondersteunde Militêre Geskiedskrywing, 1924-1987', Militaria, vol 19, no 4, 1989, p 19.

JAI Agar-Hamilton, 'The Union of South Africa War Histories' in Robin Higham, ed., Official Histories; Essays and Bibliographies from around the World, p. 443.

Preface to The Union of South Africa and the Great War, 1914-1918: Official History (Government Printing and Stationery Office, Pretoria, 1924), p 3.

The Union of South Africa and the Great War, 1914-1918, p 4.

The Union of South Africa and the Great War, 1914-1918, p 4.

Norman Clothier, Black Valour; The South African Native Labour Contingent, 1916-1918 and the sinking of the 'Mendi' (University of Natal Press, Pietermaritzburg, 1987).

Van der Byl, From Playgrounds to Battlefields, pp 87, 145.

JSM Simpson, South Africa Fights (Hodder \& Stoughton, London, 1941), p 91.

Simpson, South Africa Fights, p 91.

Brig Gen Collyer to Secretary for Defence, 25 Mar 1920, Personnel file Maj Gen JJ Collyer, Personnel Archives and Reserves, SANDF Documentation Centre.

Secretary for Defence to Brig Gen JJ Collyer, 30 Mar 1920, Personnel file Maj Gen JJ Collyer, Personnel Archives and Reserves, SANDF Documentation Centre.

Secretary for Defence to Brig Gen JJ Collyer, 30 Mar 1920, Personnel file Maj Gen JJ Collyer, Personnel Archives and Reserves, SANDF Documentation Centre.

An exception is Collyer's report on the military situation in September 1939, but there will be others in the archives of the Secretary for Defence and the Chief of the General Staff.

Simpson, South Africa Fights, p 91.

A War Office committee on the lessons of the First World War was appointed in 1932. Hew Strachan, European Armies and the Conduct of War (Routledge, London and New York, 1993), p 152; and David French, 'Failures of the Inter-War Years; Doctrine, Training and Organisation in the British Army, 19191940', Army Quarterly and Defence Journal, vol 127, no 2, 1997, pp 195-201. 
C Hordern and HM Stacke, Military Operations East Africa, vol 1: August 1914 - September 1916 (HMSO, London, 1941). Reprinted by The Battery Press, Nashville, Tennessee, in 1990. Volume 2, taking the campaign from 1916 to 1918, was interrupted by the death of the last of the authors and never published. There is a copy in TNA at Kew. See NJ Wells, Official Histories of the Great War, 19141918 (Naval \& Military Press, Uckfield, 2011), pp 53-54. Archives of the General Officer Commanding Union Defence Forces (GOC UDF), Box 18, file GOC 81 History of Campaign in East Africa, British version, SANDF Documentation Centre. Secretary for Defence to Coller, 26 May 1936, and Collyer to Brink, 6 Jun 1936, GOC UDF, Box 18, file GOC 101 SWA Campaign Preparation Military text-book by General Collyer, SANDF Documentation Centre. JJ Collyer, The Campaign in German South West Africa, 1914-1915 (Government Printer, Pretoria, 1937), preface. Secretary for Defence to Secretary for Finance, 22 May 1936, GOC UDF, Box 18, file GOC 101 SWA Campaign Preparation Military text-book by General Collyer, SANDF Documentation Centre. Gen JFC Fuller as quoted by Hew Strachan, European Armies and the Conduct of War (Routledge, London and New York, 1983), p 1. Collyer, The Campaign in German South West Africa, 1914-1915, preface. Collyer, The Campaign in German South West Africa, 1914-1915, preface.

Collyer, The Campaign in German South West Africa, 1914-1915, preface.

Collyer, The Campaign in German South West Africa, 1914-1915, preface.

Collyer, The Campaign in German South West Africa, 1914-1915, preface.

Brink to Collyer, 30 Jun 1936, GOC UDF, box 18, file GOC101 SWA Campaign Preparation Military textbook by General Collyer, SANDF Documentation Centre. Collyer to Brink, 13 Jul 1936, GOC UDF, Box 18, file GOC 101 SWA Campaign, Preparation Military textbook by General Collyer, SANDF Documentation Centre. Van der Waag, 'The battle of Sandfontein, 26 September 1914; South Africa, military reform and the German South West Africa campaign, 1914-15', pp 152-53. Hordern and Stacke used both Leipoldt's Official History and Collyer's work on East Africa. Hordern and Stacke, Military Operations; East Africa, p xix. Pretoria, 1939), preface. Ian van der Waag, A Military History of Modern South Africa (Jonathan Ball, Johannesburg and Cape Town, 2015), pp 159-64. Collyer, The South Africans with General Smuts in German East Africa, 1916, preface. SA Military College, "Bush Warfare", 9 Oct 1940, Senator JM Conradie Collection, UPA, Unisa. Smuts, 'Foreword', to Collyer, The South Africans with General Smuts in German East Africa, 1916. Van der Waag, 'Contested Histories', in Grey, ed., The Last Word?, p 36. Richard Steyn, Jan Smuts; Unafraid of Greatness (Jonathan Ball, Johannesburg, 2015), p 48. John Keegan, The Battle for History; Re-fighting World War II (Pimlico, London, 1997), p 35. 